Check for updates

Cite this: New J. Chem., 2018, 42,7746

Received 30th November 2017 Accepted 16th January 2018

DOI: 10.1039/c7nj04716a

rsc.li/njc

\title{
On the copper(II) binding of asymmetrically functionalized tripodal peptides: solution equilibrium, structure, and enzyme mimicking $\dagger$
}

\author{
Ágnes Dancs, ${ }^{\text {ab }}$ Katalin Selmeczi, (D) ${ }^{b}$ Nóra V. Mayc and Tamás Gajda (D) *a
}

\begin{abstract}
Our aim is to combine the preorganized structure of tripodal scaffolds and the advantageous metalbinding ability of histidine subunits. To this end, recently we have studied the copper(॥) complexes of the tris(L-histidyl)-functionalized tren derivative, tren3his. Here we report the copper(II)-binding properties of the mono- and bis(L-histidyl)-functionalized tren ligands (tren1his $\left(\mathbf{L}^{\mathbf{1}}\right)$ and tren2his $\left(\mathbf{L}^{\mathbf{2}}\right)$ ), and thus explore the impact of increasing histidine 'density' on the copper(॥) binding of these tripodal peptides. Our solution equilibrium study was supplemented by several (UV-vis, CD, ESR, and NMR) spectroscopic and MS methods. The mono-His derivative $\mathbf{L}^{1}$ forms only mononuclear complexes. Above $\mathrm{pH} 4$, the tren-like subunit is the main binding site, which is supplemented by an imidazole coordination. In the case of $\mathbf{L}^{\mathbf{2}}$, both mono- and dinuclear copper(II) species are formed. In the acidic-neutral pH range, the highly stable bis-histamine-type binding mode dominates in the equimolar solution, while at a higher $\mathrm{pH}$ amide coordinated complexes are present. The bis-histamine coordination in $\mathrm{CuHL}^{2}$ creates a preorganized structure, which promotes the binding of a second metal at the tren-like binding site with $\left\{\mathrm{N}^{-}, \mathrm{N}_{\text {tert }}, \mathrm{N}^{-}\right\}$ coordination in $\mathrm{Cu}_{2} \mathrm{H}_{-1} \mathrm{~L}^{2} / \mathrm{Cu}_{2} \mathrm{H}_{-2} \mathrm{~L}^{2}$. Only the dinuclear $\mathrm{Cu}_{2} \mathrm{H}_{-2} \mathrm{~L}^{2}$ complex was found to efficiently catalyze the oxidation of $\mathrm{H}_{2}$ DTBC. The kinetic data resulted in a very high $k_{\text {cat }} / K_{\mathrm{M}}$ ratio $\left(4360 \mathrm{M}^{-1} \mathrm{~s}^{-1}\right)$, which is due to the exceptionally strong substrate-binding ability of the dinuclear complex. However, the oxidation of the substrate within this adduct, which is a common feature of catalytically active dicopper(I) complexes, does not occur in the absence of dioxygen. This finding implies that the role of dioxygen is the oxidation of the substrate activated by the dinuclear complex. We assume a $\mathrm{Cu}(\|) \mathrm{Cu}(\|)-$ catecholate$\mathrm{CU}\left({ }^{\prime \prime}\right) \mathrm{Cu}(I)$-semiquinone valence tautomer (VT) equilibrium. The semiquinone formed in small quantities reacts with dioxygen in a rate-determining step, which eventually results in DTBQ and $\mathrm{H}_{2} \mathrm{O}_{2}$ products. The $\mathrm{Cu}(\mathrm{I})-\mathrm{L}^{2}$ complexes also exhibit efficient superoxide dismutase-like activity, supporting the versatility of tripodal peptide complexes in redox enzyme mimicking.
\end{abstract}

\section{Introduction}

Tripodal ligands are specially structured molecules containing several donor groups distributed among the three 'arms'. They are extensively used in coordination chemistry as complexing agents for various transition metal ions. Metal complexes of

\footnotetext{
${ }^{a}$ Department of Inorganic and Analytical Chemistry, University of Szeged, Dóm tér 7, H-6720 Szeged, Hungary. E-mail: gajda@chem.u-szeged.hu; Fax: $+36-62-544340 ;$ Tel: $+36-62-544435$

${ }^{b}$ Université de Lorraine - CNRS, UMR 7053 L2CM, BP 70239, 54506 Vandoeuvre-lès-Nancy, France

${ }^{c}$ Institute of Organic Chemistry, Research Centre for Natural Sciences HAS, Magyar tudósok körútja 2, H-1117 Budapest, Hungary

$\dagger$ Electronic supplementary information (ESI) available: Supplementary data (including measured UV-vis, CD, NMR and EPR spectra of copper(II) complexes, along with further kinetic and substrate-binding experimental data). See DOI: 10.1039/c7nj04716a
}

tripodal ligands usually exhibit elevated thermodynamic stability due to the formation of fused chelate rings, which, depending on the denticity and symmetry of the ligand, may stabilize different coordination geometries. The targeted functionalization of tripodal ligands allows the fine-tuning of metal ion binding and also the development of additional functions, e.g. molecular recognition sites, additional metal binding or substrate binding sites, etc.

Accordingly, tripodal ligands are applied in diverse fields of chemistry, such as metal sensing, ${ }^{1}$ metalloenzyme modelling, ${ }^{2-7}$ and stabilization of reactive species and intermediates ${ }^{8,9}$ and even for the development of molecular motors. ${ }^{10}$ Some tripodal ligands and/or their metal complexes show high tendency to selfassembly, creating metal-organic frameworks, ${ }^{11}$ metallocages with colorful compositions, ${ }^{12}$ hydrogels ${ }^{13}$ or other mesophase structures, ${ }^{14}$ thus expanding their application to supramolecular chemistry as well. 
The advantages of peptide-type tripodal ligands in coordination chemistry have been recognized in the last few decades. The vast majority of the metal binding tripodal peptides studied are symmetrical, tri-substituted derivatives. They proved to be useful in e.g. the development of allosteric binding cavities in supramolecular assemblies, ${ }^{15}$ targeted chelation of $\mathrm{Cu}(\mathrm{I}),{ }^{16}$ mimicry of type-3 copper-binding sites, ${ }^{17}$ structural modeling of hydrolytic enzymes, ${ }^{6,18}$ and electrocatalytic water oxidation. ${ }^{7}$ So far, only a few examples can be found in the literature on the metal complexes of histidine-containing tripodal peptides, ${ }^{6,17,18}$ although histidine moieties are the major coordination sites in most metalloproteins.

Histidine-containing linear peptides are proved to be efficient metalloenzyme mimetics, exhibiting both hydrolytic ${ }^{19,20}$ and oxidative activities. ${ }^{21-26}$ These short peptides, however, are usually highly flexible, and the metal ion environments similar to the active site of native metalloenzymes are not stabilized. As a consequence, the metal-binding ability of linear peptides, along with their catalytic efficiency, is rather limited.

For these reasons, our aim was to combine the preorganized structure of tripodal scaffolds and the advantageous metalbinding ability of histidine(s). To this end, we have synthesized two histidine derivatives based on tris(2-aminoethyl)amine (tren) and nitrilotriacetic acid (nta) as tripodal platforms, containing $\mathrm{N}$ - and C-terminal histidines (tren3his and nta3his), respectively, and studied their coordination properties with copper(II) in details. ${ }^{27}$ The formation of both mono- and oligonuclear complexes confirmed the positive influence of tripodal platforms on metal coordination. Moreover, the oligonuclear complexes of both ligands exhibited efficient catechol oxidaselike activity.

In order to explore the impact of histidine 'density' on the coordination chemistry of these tripodal peptides, we have recently synthesized two new, asymmetrically functionalized His-ligands, tren1his and tren2his (Scheme 1), and described their zinc(II) binding properties. ${ }^{28}$ The three ligands in the tren $X$ his series $(X=1,2$, and 3$)$ provide a number of donor sites for their zinc(II) complexes depending on the $\mathrm{pH}$ and metal-to-ligand ratios. The increasing level of functionalization favors the histamine-like coordination and allows the formation of oligonuclear complexes as well. Above pH 7 amide nitrogens and imidazolato-bridges also participate in zinc(II) binding, which results in a variety of structures.

Here, we report solution equilibrium and the structural as well as kinetic properties of copper(II) complexes formed with tren1his and tren2his (Scheme 1). Our aim was to explore how

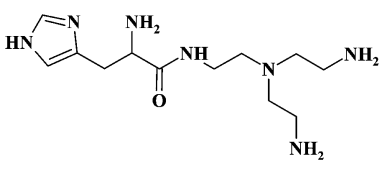

tren1his $\left(\mathbf{L}^{\mathbf{1}}\right)$

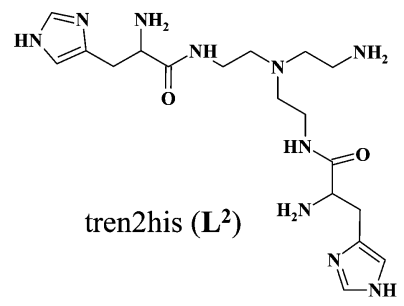

Scheme 1 Schematic structures of the investigated ligands. the increasing functionalization of tren arms affects the structure of copper(II) complexes and consequently their catalytic behaviors in catechol oxidation and superoxide dismutation.

\section{Experimental section}

\subsection{Materials}

Copper(II) perchlorate (Sigma-Aldrich) stock solution was standardized complexometrically. Potentiometric titrations have been carried out using 0.1 M standard $\mathrm{NaOH}$ solution (Sigma-Aldrich). Ethanol (VWR), 3,5-di-tert-butylcatechol ( $\mathrm{H}_{2} \mathrm{DTBC}$, Sigma-Aldrich), 2-(N-morpholino)ethanesulfonic acid (MES, Sigma-Aldrich), 4-(2-hydroxyethyl)-1-piperazineethanesulfonic acid (HEPES, Sigma-Aldrich), $\mathrm{N}$-cyclohexyl-2-aminoethanesulfonic acid (CHES, Alfa Aesar), catechol (Sigma-Aldrich), 4-nitrocatechol $\left(\mathrm{H}_{2} 4 \mathrm{NC}\right.$, Sigma-Aldrich), sodium dihydrogen phosphate $\left(\mathrm{NaH}_{2} \mathrm{PO}_{4} \cdot 2 \mathrm{H}_{2} \mathrm{O}\right.$, Sigma-Aldrich), disodium hydrogen phosphate $\left(\mathrm{Na}_{2} \mathrm{HPO}_{4} \cdot 2 \mathrm{H}_{2} \mathrm{O}\right.$, Sigma-Aldrich), xanthine (Sigma-Aldrich), xanthine oxidase (Sigma-Aldrich) and nitroblue tetrazolium chloride (NBT, Alfa Aesar) were analytically pure chemicals and used without further purification. The ligands tren1his and tren2his were prepared as previously reported. ${ }^{28}$

\subsection{Potentiometric measurements}

The protonation and coordination equilibria were investigated by $\mathrm{pH}$-potentiometric titrations in aqueous solutions $(I=0.1 \mathrm{M}$ $\mathrm{NaCl}$ and $T=298.0 \pm 0.1 \mathrm{~K}$ ) under an argon atmosphere. The titrations were performed using a PC-controlled Dosimat 665 (Metrohm) automatic burette and an Orion 710A precision digital pH meter. The Metrohm micro-glass electrode (125 mm) was calibrated by the titration of hydrochloric acid and the data were fitted using the modified Nernst equation: ${ }^{29}$

$$
E=E_{0}+K \cdot \log \left[\mathrm{H}^{+}\right]+J_{\mathrm{H}} \cdot\left[\mathrm{H}^{+}\right]+\frac{J_{\mathrm{OH}} \cdot K_{\mathrm{w}}}{\left[\mathrm{H}^{+}\right]}
$$

where $J_{\mathrm{H}}$ and $J_{\mathrm{OH}}$ are the fitting parameters representing the acidic and alkaline errors of the glass electrode, respectively $\left(K_{\mathrm{w}}=10^{-13.75}\right.$ is the autoprotolysis constant of water $\left.{ }^{30}\right)$. The parameters were calculated by the non-linear least squares method. The formation of the complexes was characterized by the general equilibrium process:

$$
\begin{gathered}
\mathrm{pM}+\mathrm{qM}+\mathrm{rL} \stackrel{\beta_{\mathrm{M}_{\mathrm{q}} \mathrm{H}_{\mathrm{q}} \mathrm{L}_{\mathrm{r}}}}{=} \mathrm{M}_{\mathrm{p}} \mathrm{H}_{\mathrm{q}} \mathrm{L}_{\mathrm{r}} \\
\beta_{\mathrm{M}_{\mathrm{q}} \mathrm{H}_{\mathrm{q}} \mathrm{L}_{\mathrm{r}}}=\frac{\left[\mathrm{M}_{\mathrm{p}} \mathrm{H}_{\mathrm{q}} \mathrm{L}_{\mathrm{r}}\right]}{[\mathrm{M}]^{\mathrm{p}}[\mathrm{H}]^{\mathrm{q}}[\mathrm{L}]^{\mathrm{r}}}
\end{gathered}
$$

where $\mathbf{M}$ denotes the metal ion and $\mathrm{L}$ the fully deprotonated ligand molecule. The charges are omitted for simplicity, but can be easily calculated taking into account the composition of the protonated ligand at $\mathrm{pH} 2\left(\left[\mathrm{H}_{4} \mathbf{L}^{1}\right]^{4+}\right.$ and $\left.\left[\mathrm{H}_{6} \mathbf{L}^{2}\right]^{6+}\right)$. The protonation constants of the ligands and the formation constants of the complexes were calculated using the PSEQUAD computer program ${ }^{31}$ from 4 and 4-7 independent titrations respectively ( $c a .90$ data points per titration). The metal ion 
concentrations varied between 1.5 and $3.0 \times 10^{-3} \mathrm{M}$, using $2: 1$, $3: 2,1: 1$ and $1: 2$ metal-to-ligand ratios.

\subsection{UV-visible absorption (UV-vis) and circular dichroism (CD) spectroscopic measurements}

UV-vis and CD spectra were recorded simultaneously on a BioLogic MOS-450 spectrometer (PMS-450 photomultiplier control unit, ALX-220 arc lamp power supply) using a quartz cuvette with a $1 \mathrm{~cm}$ optical pathlength. Data were collected in the wavelength interval of 300 to $820 \mathrm{~nm}$ at a resolution of $1 \mathrm{~nm}$. Spectral changes were monitored between $\mathrm{pH} 2$ and 11 at a $1: 1 \mathrm{Cu}(\mathrm{II})-\mathbf{L}^{\mathbf{1}}$ ratio and at $1: 1$ and $2: 1 \mathrm{Cu}(\mathrm{II})-\mathbf{L}^{2}$ ratios. The metal ion concentration was $0.9 \times 10^{-3} \mathbf{M}$ and $1.6-3.2 \times 10^{-3} \mathbf{M}$ for $\mathrm{Cu}(\mathrm{II})-\mathbf{L}^{\mathbf{1}}$ and $\mathrm{Cu}(\mathrm{II})-\mathbf{L}^{2}$ titrations, respectively. The $\mathrm{pH}$-dependent $\mathrm{UV}$-vis and $\mathrm{CD}$ spectra were processed together with the $\mathrm{pH}$-potentiometric data using the PSEQUAD computer program, ${ }^{31}$ resulting in the determination of stability constants $(\log \beta)$ as well as individual UV-vis and CD spectra of the Cu(II) complexes.

\subsection{Electron paramagnetic resonance (EPR) measurements}

The EPR spectra of the copper(II) complexes were recorded at $77 \mathrm{~K}$, as individual $\mathrm{pH}$-adjusted samples $(I=0.1 \mathrm{M} \mathrm{NaCl})$, on a Bruker EMXplus 10/12 spectrometer (microwave frequency 9.39 GHz, microwave power $9.41 \mathrm{~mW}$, modulation amplitude $5 \mathrm{G}$, and modulation frequency $100 \mathrm{kHz}$ ). The samples were prepared as aqueous solutions $\left(\left[\mathbf{L}^{\mathbf{1}}\right]_{\text {tot }}=1.56 \times 10^{-3} \mathrm{M}\right.$ and $\left[\mathbf{L}^{2}\right]_{\text {tot }}=1.70 \times 10^{-3} \mathrm{M}$, and copper(II) perchlorate solution was added according to the relevant metal-to-ligand ratio). $100 \mu \mathrm{l}$ volumes of the samples were added into the capillary, and then $20 \mu \mathrm{l}$ of methanol was added to each of the samples in order to avoid water crystallization. The frozen solution EPR spectra were simulated using the "EPR" program, ${ }^{32}$ rhombic $g$-tensors $\left(g_{x}, g_{y}\right.$, and $\left.g_{z}\right)$ and copper hyperfine tensors $\left(A_{x}, A_{y}\right.$, and $\left.A_{z}\right)$, and the orientation-dependent linewidth parameters were fitted to set up the spectra. Nitrogen hyperfine couplings were not detected owing to the poor resolution of the spectra. Since the used copper(II) salt was a natural mixture of isotopes, all spectra were calculated as the sum of the spectra containing ${ }^{63} \mathrm{Cu}$ and ${ }^{65} \mathrm{Cu}$ weighted by their natural abundance. The copper and ligand coupling constants are given in units of gauss $\left(1 \mathrm{G}=10^{-4} \mathrm{~T}\right)$.

\subsection{Matrix-assisted laser desorption/ionization time-of-flight mass spectrometric (MALDI-TOF MS) measurements}

Molecular weight analysis of the formed complexes was executed by MALDI-TOF MS using a Bruker Reflex IV MALDITOF mass spectrometer. The samples were prepared in aqueous solutions at metal-to-ligand ratios of $1: 1\left(\mathbf{L}^{1}\right.$ and $\left.\mathbf{L}^{2}\right)$ and $2: 1\left(\mathbf{L}^{2}\right)$ by adjusting the desired $\mathrm{pH}$ using $\mathrm{NaOH}$ and $\mathrm{HCl}$ solutions. $1 \mu \mathrm{l}$ of the sample was spotted onto the MALDI target plate and allowed to dry before adding $0.5 \mu \mathrm{l}$ of the matrix solution (20 mg ml $\mathrm{ml}^{-1}$ 2,5-dihydroxybenzoic acid (DHB) in water). Mass spectra were recorded in the positive reflectron mode ( $\mathrm{m} / \mathrm{z}$ range: $200-1500)$. External calibration affording $\pm 100 \mathrm{ppm}$ mass accuracy was performed using a polyethylene glycol standard (Aldrich). The DHB matrix was obtained from Sigma-Aldrich.

\subsection{Oxidation of 3,5-di-tert-butylcatechol $\left(\mathrm{H}_{2} \mathrm{DTBC}\right)$}

All measurements were performed using a PerkinElmer Lambda 1050 or a Cary3E Varian spectrophotometer.

Kinetic study. The oxidation of 3,5-di-tert-butylcatechol $\left(\mathrm{H}_{2} \mathrm{DTBC}\right)$ was followed in buffered solutions (0.02 M MES/ HEPES/CHES, $I=0.1 \mathrm{M}(0.08 \mathrm{M} \mathrm{NaCl})$, and $T=298 \mathrm{~K})$ by detecting the increase in absorption at $400 \mathrm{~nm}$ of 3,5-di-tertbutyl-o-benzoquinone (DTBQ, $\varepsilon=1900 \mathrm{M}^{-1} \mathrm{~cm}^{-1}$ ). 50\% ethanol$50 \%$ aqueous solutions were used to prevent the precipitation of DTBQ. The actual $\mathrm{pH}$ in this mixed solvent was determined by subtracting 0.21 units from the $\mathrm{pH}$-meter reading, ${ }^{33}$ and the auto-ionization constant of water in this medium is $\mathrm{p} K_{\mathrm{w}}=$ 14.84. ${ }^{34} \mathrm{O}_{2}$ concentrations were adjusted by the addition of $\mathrm{O}_{2}$-saturated EtOH to the reaction solutions in given volumes (the solubility of $\mathrm{O}_{2}$ is $250 \mathrm{mg} \mathrm{dm}^{-3}$ and $41 \mathrm{mg} \mathrm{dm}^{-3}$ in ethanol and water, respectively ${ }^{35}$ ). After mixing the ethanol and the aqueous phases, the solutions were thermostated at $298 \mathrm{~K}$ for 2-3 minutes, then the reaction was initiated by the addition of $\mathrm{H}_{2}$ DTBC as an ethanolic solution.

According to the initial reaction rates $\left(v_{\mathrm{i}}\right)$ method, the experimental data used for the calculations corresponded to $\sim 4 \%$ conversion of the initial substrate concentration. $k_{\text {obs }}$ values were determined under pseudo-first-order conditions from the slope of the increasing absorbance according to the following equation:

$$
v_{\mathrm{i}}=\mathrm{d}[\mathrm{DTBQ}] / \mathrm{d} t=\left(\varepsilon_{400 \mathrm{~nm}} \times l\right)^{-1} \times(\mathrm{d} A / \mathrm{d} t)=k_{\mathrm{obs}} \times[\mathrm{S}]_{\mathrm{o}}
$$

where $\mathrm{d} A / \mathrm{d} t$ is the slope of the fitted curve, $\varepsilon_{400}$ is the molar absorptivity of DTBQ at $400 \mathrm{~nm}, l$ is the optical pathlength, and $[\mathrm{S}]_{\mathrm{o}}$ is the initial concentration of the substrate.

Autooxidation of $\mathrm{H}_{2}$ DTBC was taken into account in every experiment, resulting in $k_{\text {obs,corr values }}\left(k_{\text {obs,corr }}=k_{\text {obs }}-k_{\text {obs,auto }}\right)$. The parameters of the Michaelis-Menten model ( $K_{\mathrm{M}}$ and $\left.k_{\text {cat }}\right)$ were calculated by the non-linear least squares method. The reported kinetic data are averages of at least three parallel measurements.

Substrate binding study. Substrate binding experiments were carried out in buffered 50\% ethanol-water solutions (0.05 M CHES, $I=0.1 \mathrm{M}(0.05 \mathrm{M} \mathrm{NaCl})$, and $T=298 \mathrm{~K})$, with regard to the $\mathrm{Cu}(\mathrm{II})-\mathbf{L}^{2}$ system using catechol, 4-nitrocatechol and $\mathrm{H}_{2}$ DTBC substrates. In each experiment, the 0-20 eq. substrate was added to the $\mathrm{pH}$-adjusted complex solution under anaerobic conditions (argon atmosphere). UV-vis and CD spectra were recorded simultaneously using a closed quartz cuvette equipped with a septum with a $1 \mathrm{~cm}$ optical pathlength. Complex concentrations were adjusted to $1.1 \times 10^{-3} \mathrm{M}$ (in $\mathrm{H}_{2}$ DTBC and catechol binding studies) and $3.5 \times 10^{-4} \mathrm{M}$ (in a 4-nitrocatechol binding study). 'Blank' experiments of $\mathrm{H}_{2}$ DTBC, in the absence of metal complexes, were also carried out to verify the anaerobic conditions.

\subsection{Superoxide dismutase (SOD) activity}

The SOD-like activity of the copper(II)-peptide complexes was studied at $298 \mathrm{~K}$ and at $\mathrm{pH} 7.4$ (0.05 M phosphate buffer) by using the indirect method of nitroblue tetrazolium (NBT) reduction, according to reported procedures. ${ }^{22,24} \mathrm{The}_{2}{ }^{\bullet-}$ radical 
was in situ generated using the xanthine/xanthine oxidase system, and the reduction of NBT was followed spectrophotometrically at $560 \mathrm{~nm}$ in $1 \mathrm{~cm}$ cuvettes using a PerkinElmer Lambda 1050 spectrophotometer. The quantity of xanthine oxidase was set to produce $\Delta A=0.025-0.05 \mathrm{~min}^{-1}$, and xanthine concentration was $1 \times 10^{-4} \mathrm{M}$ in the reaction mixture. Kinetic tests were carried out in the presence of different amounts of copper(II) complexes from 0 to $1 \times 10^{-6} \mathrm{M}$. The catalytic performance was established by calculating $\%$ inhibition, $\mathrm{IC}_{50}$ and $k$ values (as reported in the literature ${ }^{36}$ ).

\section{Results and discussion}

The protonation equilibria of both ligands have been investigated in details in our previous report ${ }^{28}$ by $\mathrm{pH}$ potentiometry and ${ }^{1} \mathrm{H}$ NMR spectroscopy (their protonation constants are listed in the legend of Table 1).

\subsection{Copper(II) complexes of tren 1 his $\left(\mathrm{L}^{1}\right)$}

The mono-histidyl-functionalized tren1his forms only mononuclear complexes in the presence of copper(II). The determined formation constants and some derived data are listed in Table 1, and the distribution curves of the copper(II)- $\mathbf{L}^{\mathbf{1}}$ species are depicted in Fig. 1. The equilibrium constant for the reaction $\mathrm{Cu}^{2+}+\mathrm{H}_{2} \mathbf{L}^{\mathbf{1}}=\mathrm{CuH}_{2} \mathbf{L}^{\mathbf{1}}(\log K=8.24)$ as well as the individual UV-vis $\left(\lambda_{\max }^{\mathrm{d}-\mathrm{d}} \sim 670 \mathrm{~nm}\right)$ and $\mathrm{CD}\left(\lambda_{\max } \sim 720 \mathrm{~nm}\right)$ spectra (Fig. 2 and Table 2) of the $\mathrm{CuH}_{2} \mathbf{L}^{\mathbf{1}}$ complex suggest histamine-like $\left\{\mathrm{N}_{\mathrm{im}}, \alpha \mathrm{NH}_{2}\right\}$ coordination in this species, similar to several HXX peptides. ${ }^{37,38}$

The formation of $\mathrm{CuHL}^{\mathbf{1}}$, which is the dominant species around $\mathrm{pH}$, induces remarkable changes in spectroscopic properties indicating a characteristically different coordination. In principle, several binding modes are possible in this species, but the intense CD spectrum (Fig. 2B) excludes the possibility of the sole coordination of the achiral tren-subunit, such as $\left\{\mathrm{NH}_{2}{ }^{\text {tren }}, \mathrm{N}_{\text {tert }}, \mathrm{NH}_{2}{ }^{\text {tren }}\right\}$. In fact, the observed 'inverse couplet' on the $\mathrm{CD}$ spectrum of $\mathrm{CuHL}^{\mathbf{1}}$ is unique and characteristic for the

Table 1 Formation constants of the $\mathrm{Cu}(I)-\mathrm{L}^{1}$ and $-\mathrm{L}^{2}$ complexes and some derived data $(I=0.1 \mathrm{M} \mathrm{NaCl}, T=298 \mathrm{~K}$, and the estimated error of last digits in parentheses). Protonation constants $(\log \beta)$ of $\mathbf{L}^{1}$ from $\mathrm{H}_{4} \mathbf{L}^{1}$ to $\mathrm{HL}^{1}$ are: $31.04,26.01,18.94$, and 9.90; those of $\mathrm{L}^{2}$ from $\mathrm{H}_{6} \mathrm{~L}^{2}$ to $\mathrm{HL}^{2}$ are: $36.46,34.13,29.51,24.10,17.28$, and $9.59^{28}$

\begin{tabular}{|c|c|c|c|c|}
\hline & \multicolumn{2}{|c|}{ tren1his $\left(\mathbf{L}^{\mathbf{1}}\right)$} & \multicolumn{2}{|c|}{ tren2his $\left(\mathbf{L}^{2}\right)$} \\
\hline & $\log \beta$ & $\mathrm{p} K$ & $\log \beta$ & $\mathrm{p} K$ \\
\hline $\mathrm{CuH}_{3} \mathrm{~L}$ & & & $30.735(2)$ & 3.197 \\
\hline $\mathrm{CuH}_{2} \mathrm{~L}$ & $27.181(6)$ & 3.951 & 27.538(1) & 4.984 \\
\hline CuHL & $23.230(8)$ & 5.931 & $22.554(4)$ & 7.173 \\
\hline CuL & $17.299(9)$ & 6.529 & $15.381(6)$ & 7.574 \\
\hline $\mathrm{CuH}_{-1} \mathrm{~L}$ & $10.77(1)$ & & $7.807(5)$ & 11.077 \\
\hline $\mathrm{CuH}_{-2} \mathrm{~L}$ & & & $-3.27(1)$ & \\
\hline $\mathrm{Cu}_{2} \mathrm{~L}$ & & & $21.906(4)$ & 4.741 \\
\hline $\mathrm{Cu}_{2} \mathrm{H}_{-1} \mathrm{~L}$ & & & $17.165(3)$ & 8.419 \\
\hline $\mathrm{Cu}_{2} \mathrm{H}_{-2} \mathrm{~L}$ & & & $8.746(4)$ & 9.368 \\
\hline $\mathrm{Cu}_{2} \mathrm{H}_{-3} \mathrm{~L}$ & & & $-0.622(5)$ & \\
\hline $\mathrm{Cu}_{3} \mathrm{H}_{-1} \mathrm{~L}_{2}$ & & & $36.72(2)$ & 7.38 \\
\hline $\mathrm{Cu}_{3} \mathrm{H}_{-2} \mathrm{~L}_{2}$ & & & $29.34(1)$ & \\
\hline
\end{tabular}

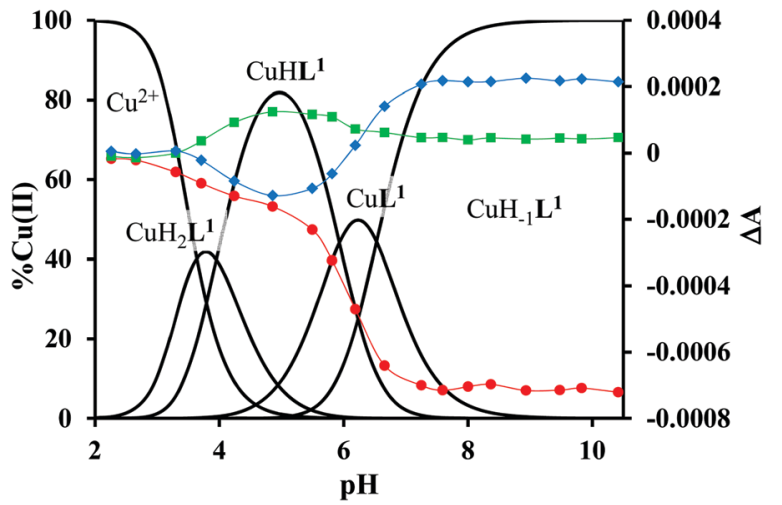

Fig. 1 Distribution of the species in the $\mathrm{Cu}(\mathrm{II})-\mathrm{L}^{1} 1: 1$ system $\left(\left[\mathrm{L}^{1}\right]_{\text {tot }}=\right.$ $[\mathrm{Cu}(\mathrm{II})]_{\mathrm{tot}}=0.001 \mathrm{M}, I=0.1 \mathrm{M} \mathrm{NaCl}$, and $\left.T=298 \mathrm{~K}\right)$. Secondary axis: measured CD intensities at $305 \mathrm{~nm}$ (red), $535 \mathrm{~nm}$ (green) and $635 \mathrm{~nm}$ (blue).

species in which chiral perturbation arises from a single histidine unit bound to copper(II) in a seven-membered $\left\{\mathrm{N}_{\mathrm{im}}, \mathrm{N}^{-}\right\}$ chelate. This type of coordination results in a very similar 'inverse CD couplet' to the copper(II) complexes of Ac-HGG-NH , Ac-HGGG-NH $\mathrm{N}_{2}$, Ac-HGGGW- $\mathrm{NH}_{2}$ and several other analogs in the octarepeat domain of the prion protein, and therefore was studied in detail. ${ }^{38-40}$ Accordingly, in $\mathrm{CuHL}^{\mathbf{1}}$ we suggest an $\left\{\mathrm{N}_{\mathrm{im}}, \mathrm{N}^{-}, \mathrm{N}_{\text {tert }}, \mathrm{NH}_{2}{ }^{\text {tren }}\right\}$ coordination (Scheme 2 ). The participation of the tertiary amino group in the coordination is the consequence of the enhanced stability of fused chelate rings. The $4 \mathrm{~N}$-coordination is also supported by the relatively highenergy $d-d$ transitions $\left(\lambda_{\max }^{\mathrm{d}-\mathrm{d}} \sim 585 \mathrm{~nm}\right)$ and the corresponding EPR parameters (see the ESI, $\uparrow$ Table S1 and Fig. S5).

Above $\mathrm{pH}$ 5, two overlapping deprotonations lead to $\mathrm{CuH}_{-1} \mathbf{L}^{\mathbf{1}}$, which is the only species present in the solution above $\mathrm{pH}$ 8. UV-vis, CD and EPR spectra indicate a considerable rearrangement of the coordination sphere during these deprotonations: the d-d transitions are red-shifted by $47 \mathrm{~nm}$ and the $g$ values are nearly unchanged, but $A_{z}$ is considerably decreased $(178 \mathrm{G} \rightarrow 157 \mathrm{G}$, Table S1, ESI $\dagger$ ). The 'inverse couplet' on the CD spectra also disappears during the $\mathrm{CuHL}^{\mathbf{1}} \rightarrow \mathrm{CuL}^{\mathbf{1}} \rightarrow \mathrm{CuH}_{-1} \mathbf{L}^{\mathbf{1}}$ transformation. These facts indicate the coordination of a further N-donor in the axial position, and therefore the changes in the coordination geometry. Tren derivatives are known to prefer pentacoordinated structures, and the spectroscopic data are in accordance with the formation of the square pyramidal geometry. In one of the two possible structures, the equatorial binding sites of $\mathrm{CuHL}^{\mathbf{1}}$ are retained, and the second tren-like $\mathrm{NH}_{2}$ group is coordinated in the apical position (Scheme 2), i.e. the $\alpha \mathrm{NH}_{3}{ }^{+}$deprotonates without metal ion assistance. Obviously, in the alternative structure, $\alpha \mathrm{NH}_{2}$ may replace the imidazole ring. In order to support one of the above-mentioned binding modes, we recorded the ${ }^{1} \mathrm{H}$ and ${ }^{13} \mathrm{C}$ NMR spectra of $\mathbf{L}^{1}$ in the presence of copper(II). The ${ }^{1} \mathrm{H}$ NMR spectra showed that the paramagnetic copper(II) induced only non-selective broadening of the signals. On the other hand, the ${ }^{13} \mathrm{C}$ NMR spectra indicated a notable broadening of the signals corresponding to the imidazole moiety $\left(\mathrm{C}^{2} \mathrm{H}, \mathrm{C}^{4}\right.$, Fig. S6, ESI $\left.\dagger\right)$ as compared to the $\alpha \mathrm{CH}$ signal. This observation suggests the participation of 

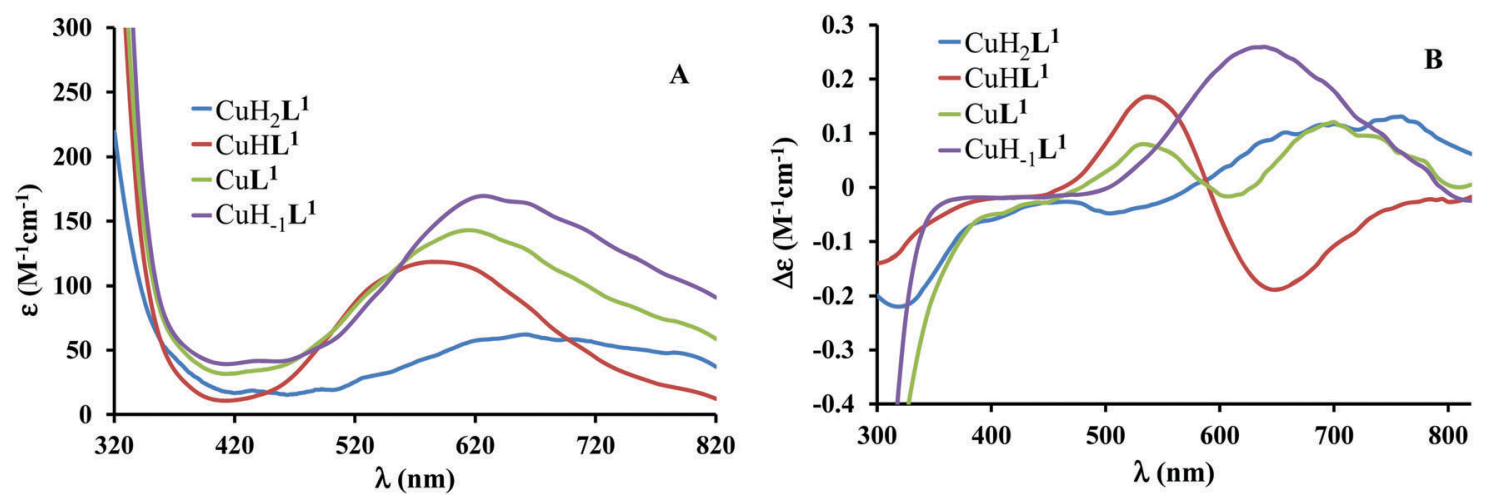

Fig. 2 Individual molar UV-vis (A) and CD (B) spectra of the forming species in the $C U(॥)-L^{\mathbf{1}} 1: 1$ system.

Table 2 Spectroscopic (UV-vis, CD and EPR) parameters of the main copper(II) $-\mathrm{L}^{1}$ and $-\mathrm{L}^{2}$ complexes

\begin{tabular}{|c|c|c|c|}
\hline Complex & $\begin{array}{l}\lambda_{\max }^{\mathrm{d}-\mathrm{d}}(\mathrm{nm}) \\
\varepsilon\left(\mathbf{M}^{-1} \mathrm{~cm}^{-1}\right)\end{array}$ & $\begin{array}{l}\lambda_{\max }^{\mathrm{CD}}(\mathrm{nm}) \\
\Delta \varepsilon\left(\mathrm{M}^{-1} \mathrm{~cm}^{-1}\right)\end{array}$ & $g_{\mathrm{o}}{ }{ }_{\mathrm{calc}}{ }^{a}$ \\
\hline $\mathrm{CuH}_{2} \mathbf{L}^{\mathbf{1}}$ & $\sim 670,60.6$ & $\sim 720,0.12$ & \\
\hline $\mathrm{CuHL}^{1}$ & $585,118.6$ & $\begin{array}{l}535,0.167 \\
645,-0.188\end{array}$ & 2.113 \\
\hline $\mathrm{CuL}^{1}$ & $615,142.9$ & $\begin{array}{l}545,0.076 \\
605,-0.016 \\
695,0.118\end{array}$ & \\
\hline $\mathrm{CuH}_{-1} \mathbf{L}^{\mathbf{1}}$ & $632,169.1$ & $\begin{array}{l}300,-1.02 \\
635,0.259\end{array}$ & 2.112 \\
\hline $\mathrm{CuH}_{2} \mathbf{L}^{2}$ & $640,53.1$ & $\begin{array}{l}305,-0.302 \\
635,0.212\end{array}$ & \\
\hline $\mathrm{CuHL}^{2}$ & $635,75.6$ & $\begin{array}{l}315,-0.616 \\
675,0.573\end{array}$ & 2.096 \\
\hline $\mathrm{CuL}^{2}$ & $580,88.0$ & $675,0.380$ & \\
\hline $\mathrm{CuH}_{-1} \mathbf{L}^{2}$ & $555,156.3$ & $\begin{array}{l}315,0.473 \\
595,0.223\end{array}$ & 2.097 \\
\hline $\mathrm{Cu}_{2} \mathbf{L}^{2}$ & $580,119.4$ & $\begin{array}{l}300,-0.884 \\
750,0.263\end{array}$ & \\
\hline $\mathrm{Cu}_{2} \mathrm{H}_{-1} \mathbf{L}^{2}$ & $570,161.1$ & $\begin{array}{l}300,1.421 \\
700,0.246\end{array}$ & 2.106 \\
\hline $\mathrm{Cu}_{2} \mathrm{H}_{-2} \mathbf{L}^{2}$ & $575,168.4$ & $\begin{array}{l}310,0.735 \\
515,-0.180 \\
670,0.347\end{array}$ & \\
\hline $\mathrm{Cu}_{2} \mathrm{H}_{-3} \mathbf{L}^{2}$ & $585,205.1$ & $\begin{array}{l}300,-0.698 \\
665,0.307\end{array}$ & 2.108 \\
\hline $\begin{array}{l}\mathrm{Cu}_{2} \mathrm{H}_{-1} \mathbf{L}^{2}-\mathrm{CuHL}^{2} \\
\mathrm{Cu}_{2} \mathrm{H}_{-3} \mathbf{L}^{2}-\mathrm{CuHL}^{2}\end{array}$ & $\begin{array}{l}546,11.3 \\
563,147.7\end{array}$ & & \\
\hline
\end{tabular}

the imidazole ring in the coordination, although the presence of the alternative structure involving the $\alpha \mathrm{NH}_{2}$ cannot be ruled out.

\subsection{Copper(II) complexes of tren2his $\left(\mathrm{L}^{2}\right)$}

The ligand tren2his forms both mono- and oligonuclear copper(II) complexes, depending on the metal-to-ligand ratios, similar to the Zn(II)-tren2his system. ${ }^{28}$ The distribution curves of the detected species are depicted in Fig. 3, and their formation constants and the spectroscopic parameters of the main species are listed in Tables 1 and 2, respectively.

In an equimolar solution, only mononuclear complexes are formed. $\mathrm{CuH}_{2} \mathbf{L}^{2}$ is the first major species around $\mathrm{pH} 4$, and its<smiles></smiles><smiles></smiles>

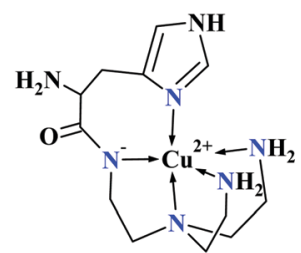

$\mathrm{CuH}_{-1} \mathbf{L}^{\mathbf{1}}$

Scheme 2 Proposed structures of the main copper(II)- $\mathrm{L}^{1}$ complexes.

protonation state suggests $3 \mathrm{~N}$ coordination. Indeed, the equilibrium constants for the process $\mathrm{Cu}^{2+}+\mathrm{H}_{2} \mathbf{L}^{2}=\mathrm{CuH}_{2} \mathbf{L}^{2}$ $(\log K=10.26)$, the UV-vis spectrum of $\mathrm{CuH}_{2} \mathbf{L}^{2}\left(\lambda_{\max }^{\mathrm{d}-\mathrm{d}} \sim 640 \mathrm{~nm}\right)$, and its relatively weak positive $\mathrm{CD}$ band between 600 and $800 \mathrm{~nm}$ are in perfect agreement with $\left\{2 \mathrm{~N}_{\mathrm{im}}, \mathrm{NH}_{2}\right\}$ coordinated complexes of several $\mathrm{HXH}^{37}$ or $\mathrm{HXXH}^{22}$ peptides.

Approaching the neutral $\mathrm{pH}$, the next deprotonation results in the formation of $\mathrm{CuHL}^{2}$. In this species, only the tren-like $\mathrm{NH}_{2}$ group is protonated, i.e. the metal ion has the highly stable bis-histamine-like $\left\{2 \mathrm{~N}_{\mathrm{im}}, 2 \alpha \mathrm{NH}_{2}\right\}$ coordination (Scheme 3 ). This binding mode is supported by spectral similarities to the analogous bis-histamine coordinated complexes: the detected $\mathrm{d}-\mathrm{d}$ transitions $\left(\lambda_{\max }^{\mathrm{d}-\mathrm{d}}=635 \mathrm{~nm}\right.$, Table 2$)$ and CD spectra (an intense positive CD peak at $675 \mathrm{~nm}$ and a negative band around $300 \mathrm{~nm}$ ) are nearly identical to those observed in $\mathrm{Cu}(\mathrm{II})$-HisGly, ${ }^{41}$ $\mathrm{Cu}(\mathrm{II})$-His-Xaa-Xaa, ${ }^{38} \mathrm{Cu}(\mathrm{II})-N, N^{\prime}$-dihistidylethane-1,2-diamine ${ }^{42}$ and in the strongly related $\mathrm{Cu}(\mathrm{II})$-tren3his systems. ${ }^{27}$

The tren-like amino group in the bis-histamine coordinated structure of $\mathrm{CuHL}^{2}$ is too far from the metal ion to be axially coordinated. Nevertheless, the $\mathrm{p} K$ values of the subsequent two deprotonation steps are more than 2 units lower than the corresponding $\mathrm{pK}(=9.59)$ in the free ligand. These facts and the fundamental spectroscopic changes (Fig. 5 and Fig. S5, ESI $\dagger$ ) during the consecutive deprotonation steps $\left(\mathrm{CuHL}^{2} \rightarrow \mathrm{CuL}^{2} \rightarrow \mathrm{CuH}_{-1} \mathbf{L}^{2}\right)$ indicate the rearrangement of the coordination sphere. The changes 

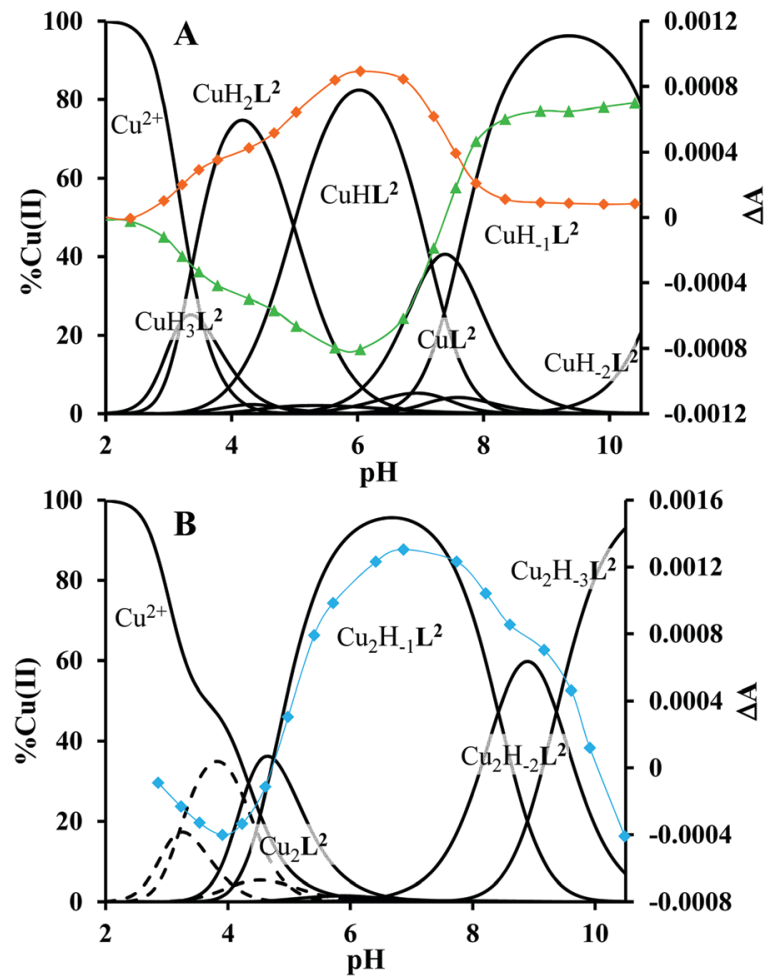

Fig. 3 Distribution of the species in $C u(I)-L^{2} 1: 1$ (A) and 2:1 (B) systems $\left(\left[\mathrm{L}^{2}\right]_{\text {tot }}=0.001 \mathrm{M},[\mathrm{Cu}(\mathrm{II})]_{\text {tot }}=0.001 \mathrm{M}\right.$ and $0.002 \mathrm{M}$, respectively, $I=0.1 \mathrm{M}$ $\mathrm{NaCl}$, and $T=298 \mathrm{~K})$. Secondary axis: measured $\mathrm{CD}$ intensities at $325 \mathrm{~nm}$ (A: green, B: blue) and $675 \mathrm{~nm}$ (orange).
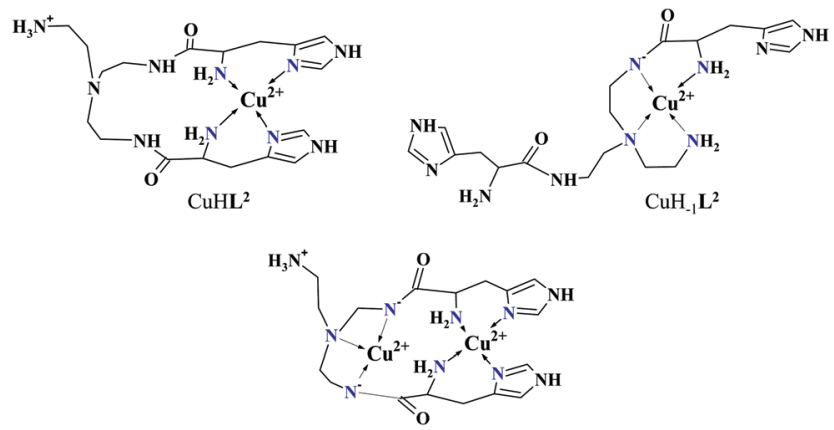

$\mathrm{Cu}_{2} \mathrm{H}_{-1} \mathbf{L}^{2}$

Scheme 3 Proposed structures for the main copper(॥)- $\mathrm{L}^{2}$ complexes.

in the CD spectra (Fig. 5B) support different coordination modes of the histidyl unit(s) in $\mathrm{CuHL}^{2}$ and $\mathrm{CuH}_{-1} \mathbf{L}^{2}$. The important blue shift of the copper(II) d-d bands (635 $\rightarrow 555 \mathrm{~nm}$, Fig. 5A) indicates a considerable increase in the ligand field strength around the metal ion, i.e. $4 \mathrm{~N}$ coordination with at least one amide nitrogen. Indeed, since the free ligand is non-protonated around $\mathrm{pH} 10$, the protonation state of the complex suggests one coordinated amide nitrogen. Considering the preferred formation of fused chelate rings as well, an $\left\{\alpha \mathrm{NH}_{2}, \mathrm{~N}^{-}, \mathrm{N}_{\text {tert }}, \mathrm{NH}_{2}{ }^{\text {tren }}\right\}$ coordination mode can be assumed in $\mathrm{CuH}_{-1} \mathbf{L}^{2}$ (Scheme 3). This donor set is very similar to that proposed above for $\mathrm{CuHL}^{\mathbf{1}}$ (Scheme 2), except that of the $\alpha \mathrm{NH}_{2} / \mathrm{N}_{\mathrm{im}}$ switch. The preference of the $\alpha \mathrm{NH}_{2}$ coordination over the imidazole ring in the present case is comprehensible, considering the more basic $\mathrm{pH}$ (the maximum formation of $\mathrm{CuHL}^{1} / \mathrm{CuH}_{-1} \mathbf{L}^{2}$ is at $\mathrm{pH} 5 / 9.5$, respectively). A further support of the suggested coordination mode arises from the similarities of CD spectra observed for the $\mathrm{CuHL}^{1} / \mathrm{CuH}_{-1} \mathbf{L}^{2}$ pair, and those reported ${ }^{38}$ for the $\mathrm{CuH}_{-2} \mathrm{~L}$ complexes of Ac-HGG-NH ${ }_{2} / \mathrm{HGG}$ peptides, where the chiral perturbation arises from the $\left\{\mathrm{N}_{\mathrm{im}}, \mathrm{N}^{-}\right\} /\left\{\alpha \mathrm{NH}_{2}, \mathrm{~N}^{-}\right\}$chelate rings, respectively.

It must be pointed out that the proposed $\left\{\alpha \mathrm{NH}_{2}, \mathrm{~N}^{-}, \mathrm{N}_{\text {tert }}, \mathrm{NH}_{2}{ }^{\text {tren }}\right\}$ coordination mode in $\mathrm{CuH}_{-1} \mathbf{L}^{2}$ leaves a histidyl-functionalized arm free, with an unbound histamine-type binding site. As was previously observed in the case of the tren3his ligand, a free N-terminal His arm induces dimerization processes in the presence of excess metal ions via the formation of $\mathrm{Cu}_{3} \mathrm{H}_{-x} \mathrm{~L}_{2}$-type complexes, ${ }^{27}$ due to the high stability offered by the bis-histamine-type binding for the third metal ion. Accordingly, the presence of trinuclear complex(es) was detected by MALDI-TOF MS (Fig. 4) at a copper(II)-to-ligand ratio of $3: 2$. The evaluation of our potentiometric data indicated the formation of two trinuclear species $\left(\mathrm{Cu}_{3} \mathrm{H}_{-1} \mathbf{L}_{2}^{2}\right.$ and $\left.\mathrm{Cu}_{3} \mathrm{H}_{-2} \mathbf{L}_{2}^{2}\right)$, since their consideration was found to be necessary for the successful fitting of the titration curves performed at a copper(II)/L $\mathbf{L}^{2}$ ratio of $3: 2$. However, these species do not form in significant quantities at $1: 1$ or $2: 1$ metal-to-ligand ratios, because of the high stability of both mono- and dinuclear complexes of $\mathbf{L}^{2}$, which were also detected by MALDI-TOF MS (Fig. 4).

The obtained isotopic distributions are in agreement with those calculated for the $\left[\mathrm{Cu}^{\mathrm{II}} \mathrm{H}_{-1} \mathbf{L}^{2}\right]^{+},\left[\mathrm{Cu}_{3}^{\mathrm{II}} \mathrm{H}_{-5} \mathbf{L}_{3}{ }_{3}\right]^{+}$and $\left[\mathrm{Cu}_{2}{ }_{2} \mathrm{H}_{-3} \mathbf{L}^{2}\right]^{+}$ complexes with single positive charges. There is, however, a unit difference per metal ion in the $\mathrm{m} / \mathrm{z}$ values between the measured and calculated spectra, which is due to the reduction of the copper(II) centers and the concomitant proton uptakes leading to $\left[\mathrm{Cu}^{\mathrm{I}} \mathbf{L}^{2}\right]^{+},\left[\mathrm{Cu}_{3}^{\mathrm{I}} \mathrm{H}_{-2} \mathbf{L}_{3}{ }_{3}\right]^{+}$and $\left[\mathrm{Cu}_{2}^{\mathrm{I}} \mathrm{H}_{-1} \mathbf{L}^{2}\right]^{+}$species. The reduction of copper(II) during the ionization process of MALDI-TOF MS has been previously observed ${ }^{27}$ and proved ${ }^{43}$ by us and was also described in several other reports dealing with copper(II) complexes. ${ }^{44-46}$

The fact that in equimolar solutions the dinuclear complexes form only in small quantities indicates that $\mathbf{L}^{2}$ provides two coordination sites for copper(II) with rather different metal binding affinities. At a 2:1 metal-to-ligand ratio, the deprotonation of first appeared minor dinuclear species $\mathrm{Cu}_{2} \mathbf{L}^{2}$ results in the formation of $\mathrm{Cu}_{2} \mathrm{H}_{-1} \mathbf{L}^{2}$ (Fig. 3B), which predominates in the solution between $\mathrm{pH} 5$ and 8. Taking into account that in the same $\mathrm{pH}$ range the bis-histamine-like $\left\{2 \mathrm{~N}_{\mathrm{im}}, 2 \alpha \mathrm{NH}_{2}\right\}$ coordination provides high stability in an equimolar solution, the conservation of this binding site in $\mathrm{Cu}_{2} \mathrm{H}_{-1} \mathbf{L}^{2}$ is safe to assume. In this manner, the four N-donors of the tren-like subunit are preorganized to bind a further metal ion. The protonation state of $\mathrm{Cu}_{2} \mathrm{H}_{-1} \mathbf{L}^{2}$ implies that the second copper(II) is bound to either an $\left\{\mathrm{N}^{-}, \mathrm{N}_{\text {tert }}, \mathrm{NH}_{2}{ }^{\text {tren }}\right\}$ or $\left\{\mathrm{N}^{-}, \mathrm{N}_{\text {tert }}, \mathrm{N}^{-}\right\}$donor set (with a protonated trenlike amino group in the latter case, see Scheme 3). Assuming that the $\left\{2 \mathrm{~N}_{\mathrm{im}}, 2 \alpha \mathrm{NH}_{2}\right\}$ coordinated metal ion in $\mathrm{Cu}_{2} \mathrm{H}_{-1} \mathbf{L}^{2}$ has a similar component UV-vis spectrum as $\mathrm{CuHL}^{2}$, the $\left(\mathrm{Cu}_{2} \mathrm{H}_{-1} \mathbf{L}^{2}-\mathrm{CuHL}^{2}\right)$ difference spectrum may be informative regarding the coordination environment around the second metal ion. This subtraction resulted in an 'usual' UV-vis spectrum (Fig. 5A) with a 

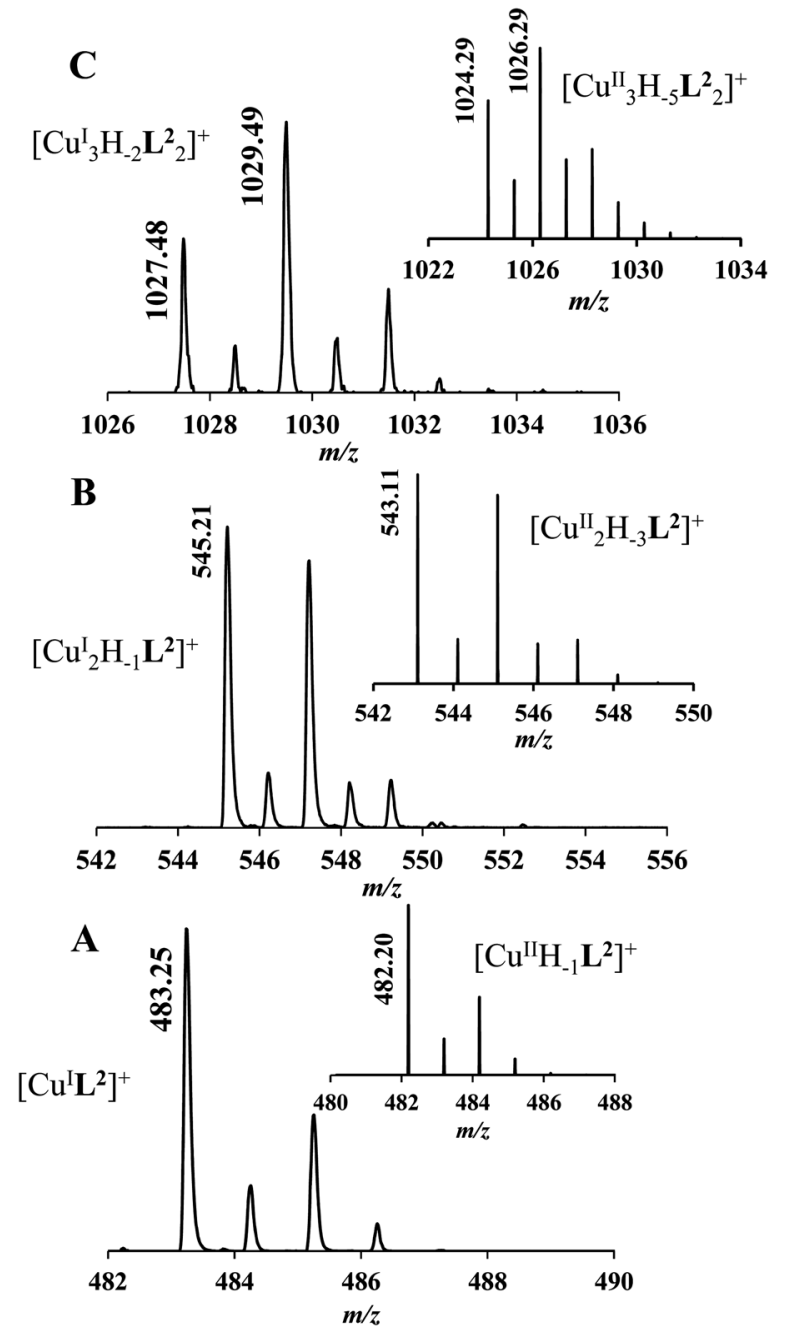

Fig. 4 MALDI-TOF MS spectra measured at $\mathrm{Cu}(\mathrm{II})-\mathrm{L}^{2} 1: 1$ (A), $2: 1$ (B) and $3: 2$ (C) ratios. Inset: Calculated spectra of the corresponding complexes: $\left[\mathrm{C}_{18} \mathrm{H}_{31} \mathrm{~N}_{10} \mathrm{O}_{2} \mathrm{Cu}_{2}\right]^{+}(\mathrm{A}),\left[\mathrm{C}_{18} \mathrm{H}_{29} \mathrm{~N}_{10} \mathrm{O}_{2} \mathrm{Cu}_{2}\right]^{+}$(B) and $\left[\mathrm{C}_{36} \mathrm{H}_{59} \mathrm{~N}_{20} \mathrm{O}_{4} \mathrm{Cu}_{3}\right]^{+}$(C).

relatively high-energy d-d maximum $\left(\lambda_{\max }^{\mathrm{d}-\mathrm{d}}=546 \mathrm{~nm}\right)$, which favors the $\left\{\mathbf{N}^{-}, \mathbf{N}_{\text {tert }}, \mathbf{N}^{-}\right\}$coordination in the equatorial plane of the second copper(II). Although none of the above-mentioned two donor sets can be ruled out, the latter one may also explain the practically unchanged UV-vis and CD spectra during the next deprotonation, i.e. deprotonation of the tren-like $\mathrm{NH}_{3}{ }^{+}$group without metal ion assistance. In fact, the processes $\mathrm{Cu}_{2} \mathrm{H}_{-1} \mathbf{L}^{2} \rightarrow$ $\mathrm{Cu}_{2} \mathrm{H}_{-2} \mathbf{L}^{2} \rightarrow \mathrm{Cu}_{2} \mathrm{H}_{-3} \mathbf{L}^{2}$ are overlapped (Fig. 3B). During the last deprotonation, proton loss of either a coordinated water molecule or an imidazole ring can be taken into account.

\subsection{Oxidation of 3,5-di-tert-butylcatechol $\left(\mathrm{H}_{2} \mathrm{DTBC}\right)$}

Our aim was to explore the effect of the increasing histidyl functionalization of tren arms on the catechol oxidase mimicking properties of the formed copper(II) complexes. Catechol oxidases are type- 3 copper enzymes, ${ }^{47,48}$ therefore the copper(II) complexes of trenXhis $(X=1,2$, and 3) ligands are well suited for such biomimetic studies, and provide a decent possibility for the structure/nuclearity/activity comparison.
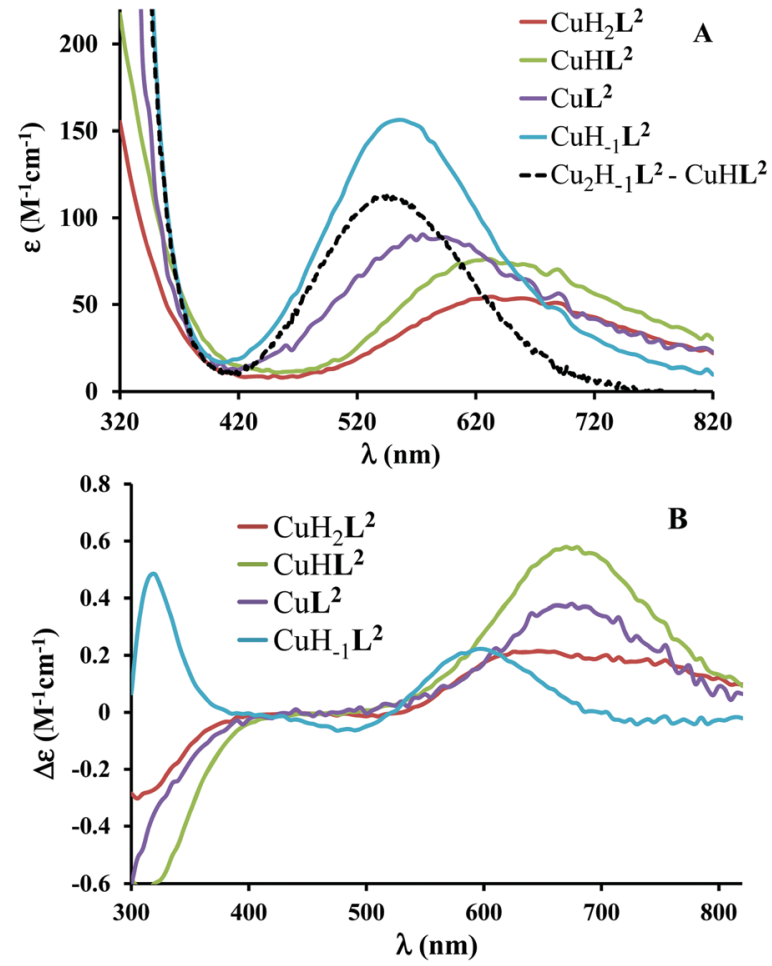

Fig. 5 Individual molar UV-vis (A) and CD (B) spectra of the main species in the $C u(I I)-L^{2} 1: 1$ system. Black dashed line corresponds to the difference spectrum of species $\mathrm{Cu}_{2} \mathrm{H}_{-1} \mathrm{~L}^{2}$ and $\mathrm{CuHL}^{2}$.

In order to understand the activation of dioxygen by metalloenzymes, a large number of dinuclear copper(II) complexes, as biomimetic models of catechol oxidase, have been investigated. ${ }^{49-53}$ Nevertheless, very few studies report the catechol oxidase activity of copper(II)-peptide complexes, ${ }^{21,54,55}$ and for this purpose tripodal peptides have been studied only by us. ${ }^{27}$

The reaction was followed by the formation of the product 3,5-di-tert-butyl-o-benzoquinone (DTBQ) spectrophotometrically at $400 \mathrm{~nm}$ in a $50 \% \mathrm{EtOH} / \mathrm{H}_{2} \mathrm{O}$ solvent, in order to enhance the solubility of DTBQ. The observed catechol oxidase-like activity strongly depends on the applied ligand and the nuclearity of the complexes. $\mathbf{C u}(\mathrm{II})-\mathbf{L}^{1}$ complexes were found to be inactive. The mononuclear complexes of $\mathbf{L}^{2}$ showed only moderate activity, although the $\mathrm{pH}$ maximum falls advantageously in the neutral $\mathrm{pH}$ range $\left(\mathrm{pH}_{\text {corr }} \sim 7.4\right.$, Fig. S7, ESI $\left.\dagger\right)$. On the other hand, the dinuclear complexes of tren2his $\left(\mathbf{L}^{2}\right)$ were found to be highly active. Therefore, a detailed kinetic study was performed only in the $\mathrm{Cu}(\mathrm{II})-\mathbf{L}^{2} 2: 1$ system.

The pH-rate constant profile for $\mathrm{H}_{2} \mathrm{DTBC}$ oxidation catalyzed by dinuclear copper(II) complexes is a maximum curve with a pH optimum around 8.7 (Fig. S7, ESI $\dagger$ ). The oxidation of the substrate should proceed through the formation of a complex$\mathrm{DTBC}^{2-}$ ternary adduct. ${ }^{49}$ This is a pH-dependent process, thus the presence of the strong metal ion binder $\mathrm{H}_{2} \mathrm{DTBC}$ obviously alters the complex formation equilibria. In this manner, the pH-rate constant profile is not directly comparable with the speciation of the binary complexes. Nevertheless, Fig. S7 (ESI $\dagger$ ) suggests that the observed catalytic activity is mainly related to 

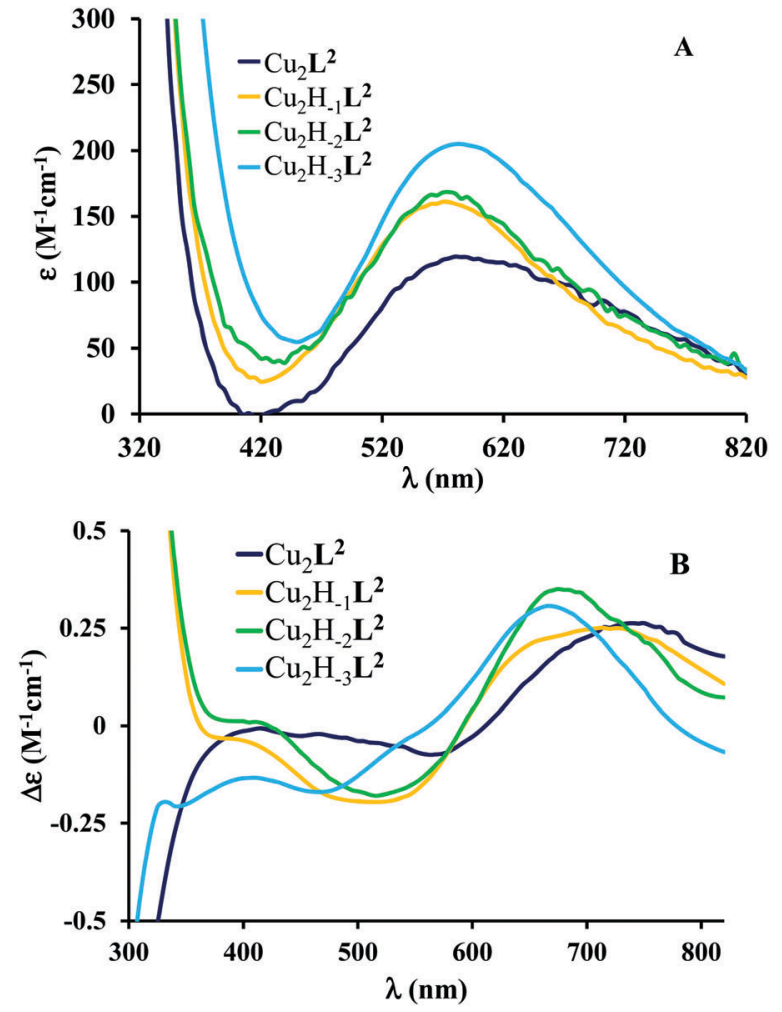

Fig. 6 Individual molar UV-vis (A) and CD (B) spectra of the main species in the $\mathrm{Cu}(I)-\mathrm{L}^{2} 2: 1$ system.

the $\mathrm{Cu}_{2} \mathrm{H}_{-2} \mathbf{L}^{2}$ species. This was also supported by our $\mathrm{CD}$ measurements (Fig. 8B): the CD spectrum of the binary system at the $\mathrm{pH}$ optimum in a $50 \% \mathrm{EtOH} / \mathrm{H}_{2} \mathrm{O}$ solvent is very similar to that obtained in an aqueous solution for $\mathrm{Cu}_{2} \mathrm{H}_{-2} \mathbf{L}^{2}$, and significantly different, especially in the UV region, from that of $\mathrm{Cu}_{2} \mathrm{H}_{-3} \mathbf{L}^{2}$ (Fig. 6B).

At the optimal $\mathrm{pH}$, the initial rate of oxidation shows saturation kinetics above 40-fold excess of the substrate over the dinuclear complexes (Fig. 7). This is in accordance with the Michaelis-Menten enzyme kinetic model, indicating a fast pre-equilibrium between the substrate and the active complex before the subsequent ratedetermining formation of the product. The non-linear regression

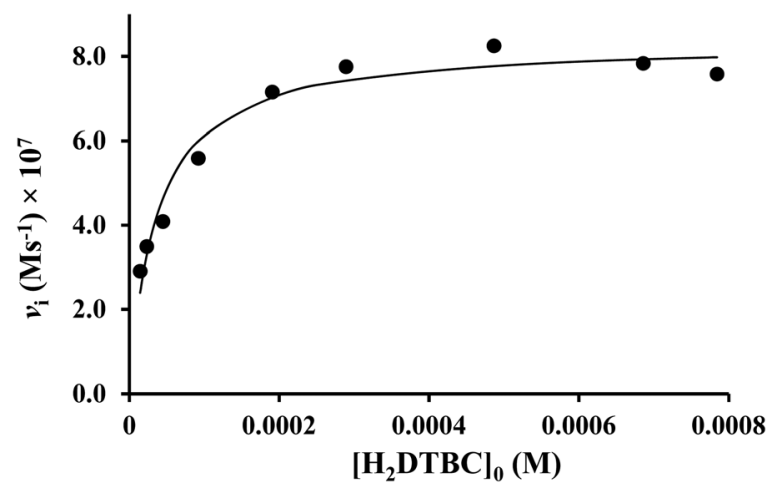

Fig. 7 Dependence of the initial reaction rates on $\mathrm{H}_{2}$ DTBC concentrations promoted by the $\mathrm{Cu}(\mathrm{II})-\mathrm{L}^{2} 2: 1$ system (in $\mathrm{EtOH} / \mathrm{H}_{2} \mathrm{O} 50 / 50 \%$, $\mathrm{pH}_{\text {corr }}=8.7$, [complex $]_{\text {tot }}=5.3 \times 10^{-6} \mathrm{M}$ ). of the kinetic data (solid line in Fig. 7) resulted in $k_{\text {cat }}=(0.157 \pm$ $0.005) \mathrm{s}^{-1}$ and $K_{\mathrm{M}}=(0.036 \pm 0.005) \mathrm{mM}$. The overall catalytic efficiency $\left(k_{\text {cat }} / K_{\mathrm{M}}\right)$ of the dicopper(II)- $\mathbf{L}^{2}$ system at $\mathrm{pH} 8.7$ is very high $\left(k_{\text {cat }} / K_{\mathrm{M}}=4360 \mathrm{M}^{-1} \mathrm{~s}^{-1}\right)$. To the best of our knowledge, only two dicopper(II) complexes were reported to have a higher efficiency ${ }^{50,52}$ The key feature of this high catalytic efficiency seems to be the exceptionally strong substrate binding to the dinuclear species, as indicated by the very low $K_{\mathrm{M}}$ value, since $k_{\text {cat }}$ is in the range generally observed for active dicopper(II) complexes. ${ }^{56}$

In order to gain further insights into the catalysis, reaction rates were also measured as a function of the concentration of dinuclear complexes and dioxygen under pseudo-first order conditions (Fig. S8, ESI $\dagger$ ). In both cases, the first-order dependence was observed, similarly to many previously investigated catecholase model systems. ${ }^{51,57-59}$ As a consequence of the Michaelis-Menten model, the observed pseudo-second order rate constant $\left(k^{\prime}\right.$, the slope of the straight line in Fig. S8, ESI $\dagger$ ) should be equal to $k_{\text {cat }} /\left(K_{\mathrm{M}}+[\mathrm{S}]\right)$. The value calculated from the Michaelis-Menten parameters $\left(k_{\text {calc }}{ }^{\prime}=272 \mathrm{M}^{-1} \mathrm{~s}^{-1}\right)$ is, indeed, relatively in good agreement with the measured one $\left(k^{\prime}=154.4 \mathrm{M}^{-1} \mathrm{~s}^{-1}\right)$.

\subsection{Substrate binding study}

Since the $K_{\mathrm{M}}$ value obtained from the saturation kinetic data indicated impressively high substrate-binding affinity for the dinuclear complexes, we wanted to verify it by an independent method, and to collect further data on the complex-substrate adduct. To this end, spectrophotometric and CD measurements have been performed as a function of substrate concentration under inert conditions (argon atmosphere), in order to prevent the catalytic oxidation of $\mathrm{H}_{2} \mathrm{DTBC}$ (Fig. 8). Upon addition of increasing amount of $\mathrm{H}_{2}$ DTBC, two overlapping bands appear in the UV-vis spectra between 350 and $450 \mathrm{~nm}$, while the $\mathrm{d}-\mathrm{d}$ band of $\mathrm{Cu}$ (II) shifts towards higher energies (from $\sim 580$ to $564 \mathrm{~nm}$, Fig. 8A). Neither the strong absorbance of DTBQ at $400 \mathrm{~nm}$ (which would have resulted in an absorbance of $\sim 1$, within the applied experimental conditions) nor the reduction of copper(II), i.e. decrease of the $\mathrm{d}-\mathrm{d}$ band intensity, was detected (Fig. 8). Consequently, the stoichiometric oxidation of the substrate by the copper(II) centers does not occur under anaerobic conditions. The absorption bands between 350 and $450 \mathrm{~nm}$ can be attributed to the CT band of the copper(II)bound catecholate, ${ }^{57,60-62}$ overlapped with the absorbance of the free (unbound) mono-deprotonated $\mathrm{HDTBC}^{-}$present in small quantities $\left(\mathrm{p} K_{\mathrm{H}_{2} \mathrm{DTBC}}=10.35\right.$ in $50 / 50 \% \mathrm{MeOH} / \mathrm{H}_{2} \mathrm{O}$ medium ${ }^{63}$ ), causing a continuous increase in absorbance at higher $\mathrm{H}_{2}$ DTBC concentrations.

The CD spectra, reflecting exclusively the environment of the metal ions, also show profound changes upon addition of $\mathrm{H}_{2} \mathrm{DTBC}$ (Fig. 8B), indicating important rearrangement of the coordination sphere upon substrate binding. Since the chiral perturbation arises exclusively from the $\mathbf{L}^{2}$ ligand, the $\mathrm{CD}$ spectra directly prove the formation of the $\mathrm{Cu}(\mathrm{II})-\mathbf{L}^{2}$-substrate adduct.

The development of the characteristic CD band at $448 \mathrm{~nm}$ (Fig. 8B inset) allowed estimating the apparent stability constant $\left(K_{\text {app }}\right)$ of the complex-substrate adduct according to the 

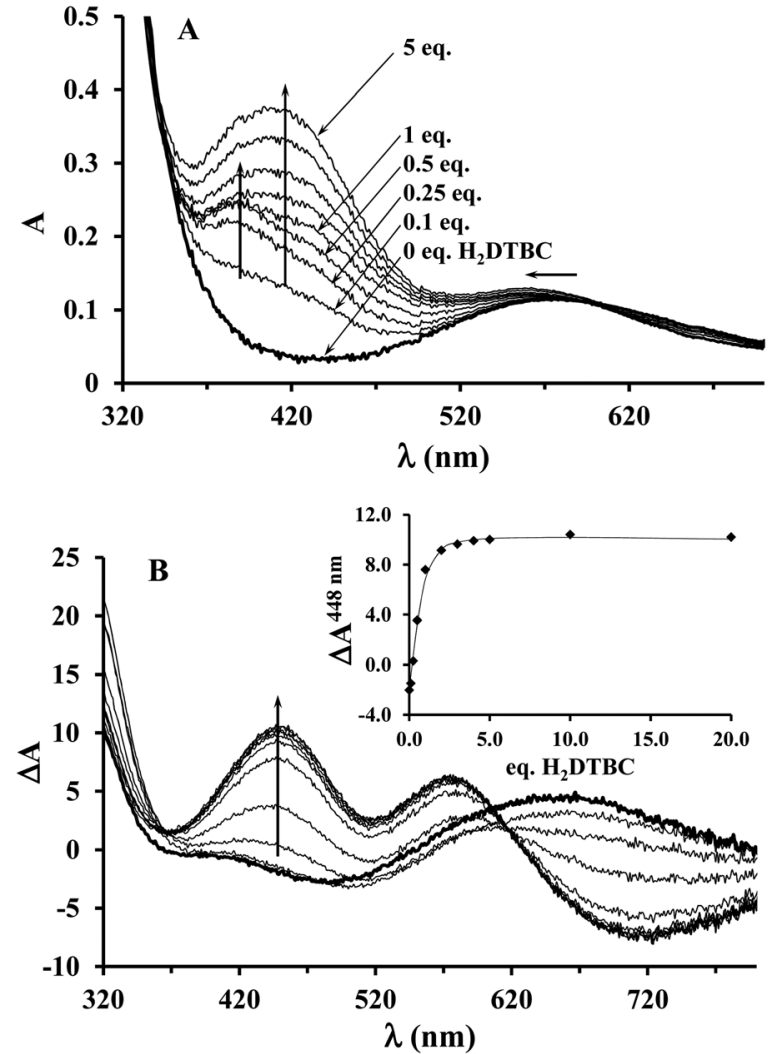

Fig. 8 UV-vis (A) and CD spectra (B) of the $C U(I)-L^{2} 2: 1$ system recorded under inert (argon) conditions, upon addition of $0-20$ eq. $\mathrm{H}_{2}$ DTBC (in $\mathrm{EtOH} / \mathrm{H}_{2} \mathrm{O} 50 / 50 \%, \mathrm{pH}_{\text {corr }}=8.7$, [complex $]_{\text {tot }}=5.3 \times 10^{-4} \mathrm{M}$ ). Inset: $\mathrm{CD}$ intensities at $448 \mathrm{~nm}$ as a function of added $\mathrm{H}_{2}$ DTBC equivalents.

equilibrium process $\mathrm{Cu}_{2} \mathrm{H}_{x} \mathbf{L}^{2}+\mathrm{H}_{2} \mathrm{DTBC}=\mathrm{Cu}_{2} \mathrm{H}_{y} \mathbf{L}^{2}\left(\mathrm{DTBC}^{2-}\right)$. The non-linear regression of the data resulted in $K_{\text {app }}=$ $14200 \mathrm{M}^{-1}$, which is in good agreement with the results of our saturation kinetic measurements $\left(1 / K_{\mathrm{M}}=27624 \mathrm{M}^{-1}\right.$, since the Michaelis constant corresponds to the dissociation constant of the above-mentioned adduct). It is worth mentioning that this extraordinary binding ability is not restricted to $\mathrm{H}_{2}$ DTBC; similarly high $K_{\text {app }}$ values $\left(>20000 \mathrm{M}^{-1}\right)$ were determined for catechol and 4-nitrocatechol as well by similar CD measurements (Fig. S9, ESI $\dagger$ ).

The observation that the two-electron oxidation of $\mathrm{H}_{2} \mathrm{DTBC}$ does not occur under anaerobic conditions is rare among dinuclear complexes, which are catalytically active in the presence of dioxygen, ${ }^{27,51,62}$ but typical for catechol oxidase mimicking mononuclear complexes. ${ }^{49,56}$ This feature clearly emphasizes that dioxygen is directly involved in the oxidation of the substrate, i.e. the mechanism is different from that proposed for the native enzyme. ${ }^{47,48}$ Although two-electron transfer from the copper(II) ions to the substrate does not occur in the present case, the metal centers are obviously involved in the activation of the substrate. Although, even zinc(II) is able to activate $\mathrm{H}_{2} \mathrm{DTBC}$ by coordination, ${ }^{64}$ in the case of copper(II) complexes the presence of a $\mathrm{Cu}$ (II)Cu(II)catecholate/ $\mathrm{Cu}$ (II) $\mathrm{Cu}(\mathrm{I}$ )-semiquinone valence tautomerism (VT) is safe to assume (Scheme 4$).^{57,65-67}$
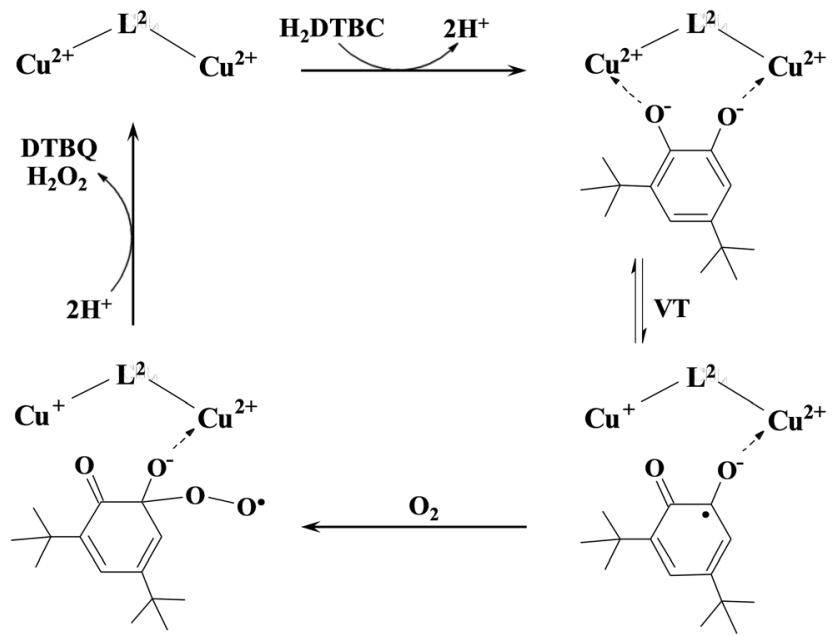

Scheme 4 A proposed mechanism for the catalytic oxidation of 3,5-ditert-butylcatechol by the dicopper(I) complex of $\mathbf{L}^{2}$.

Table 3 Kinetic (Michaelis-Menten) parameters of the investigated $\mathrm{Cu}(I)-\mathrm{L}^{2}$ system, compared with other catechol oxidase mimicking tripodal peptide complexes

\begin{tabular}{lllll}
\hline Complex & $k_{\text {cat }}\left(\mathrm{s}^{-1}\right)$ & $K_{\mathrm{M}}(\mathrm{M})$ & $\begin{array}{l}k_{\text {cat }} / K_{\mathrm{M}} \\
\left(\mathrm{M}^{-1} \mathrm{~s}^{-1}\right)\end{array}$ & Ref. \\
\hline $\begin{array}{l}\mathrm{Cu}(\mathrm{II})-\mathrm{L}^{2} 2: 1 \\
\mathrm{pH} \text { corr }=8.7\end{array}$ & $0.157(5)$ & $3.6(5) \times 10^{-5}$ & 4360 & This work \\
$\mathrm{Cu}(\mathrm{II})$-nta3his 2:1 & 0.387 & $1.07 \times 10^{-4}$ & 3625 & 27 \\
$\mathrm{pH}$ corr $=8.9$ & & & \\
$\begin{array}{l}\mathrm{Cu}(\mathrm{II}) \text {-tren3his 3:2 } \\
\mathrm{pH} \text { corr }=7.8\end{array}$ & 0.071 & $1.12 \times 10^{-4}$ & 63 & 27 \\
\hline
\end{tabular}

A similar VT was reported for a dicopper(II) complex with $\eta^{1}: \eta^{1}$ bridged catecholate as well. ${ }^{51}$ The absorption band observed between 350 and $450 \mathrm{~nm}$ (Fig. 8A) may correspond to both bidentate and $\eta^{1}: \eta^{1}$ bridged coordination of catecholate; however, the observed very low $K_{\mathrm{M}}$ favors the formation of the catecholate bridge. The above-mentioned VT equilibrium is strongly shifted toward the initial state, since neither appreciable decrease of the $\mathrm{d}-\mathrm{d}$ band intensity nor the EPR spectrum of the semiquinone radical was observed under anaerobic conditions. Nevertheless, the semiquinone formed in small quantities reacts with dioxygen in a rate-determining step, resulting in the formation of oxygenated radical intermediate(s). ${ }^{56} \mathrm{After}$ a subsequent intramolecular electron transfer DTBQ and $\mathrm{H}_{2} \mathrm{O}_{2}$ products are released, regenerating the dicopper(II) complex and allowing the coordination of a new substrate (Scheme 4). This mechanism is similar to that proposed for the copper(II) complexes of the tris-histidyl analog tren3his, ${ }^{27}$ although the presently investigated system is more active (see Table 3).

\subsection{Superoxide dismutase (SOD) activity}

The $\mathrm{Cu}(\mathrm{II})$-tren2his system, together with the previously investigated copper(II)-tren 3 his complexes, ${ }^{27}$ demonstrated strong ability for dioxygen activation via radical formation. Such oxidative reactions may involve the formation of a superoxide radical as well. Copper(II) complexes of His-containing linear peptides are wellknown superoxide dismutase mimicking compounds. ${ }^{22-25,68-70}$ 


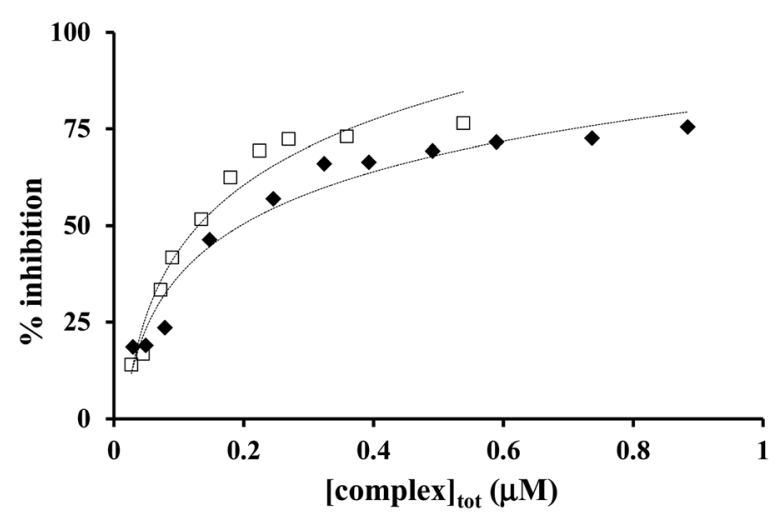

Fig. 9 Inhibition of the NBT-superoxide reaction in the presence of $\mathrm{Cu}(I I)-\mathrm{L}^{2} 1: 1(\checkmark)$ and $2: 1(\square)$ systems at $\mathrm{pH} 7.4$ (in phosphate buffer, $[\mathrm{NBT}]=2 \times 10^{-4} \mathrm{M}$ and $\left.T=298 \mathrm{~K}\right)$.

Therefore, we also studied the superoxide-dismutating ability of copper(II) complexes formed with our tripodal His-peptides, thus gaining deeper insights into their redox enzyme mimicking properties.

The SOD activity of the copper(II) $-\mathbf{L}^{\mathbf{1}}$ and $-\mathbf{L}^{2}$ systems has been characterized according to the modified McCordFridovich method, ${ }^{71}$ at a $\mathrm{pH}$ of 7.4. Similar to the catechol oxidase mimetic study, the copper(II) complexes of $\mathbf{L}^{\mathbf{1}}$ were found to be completely inactive, implying the low accessibility of the copper(II) ion, unambiguously due to the saturated and highly stable coordination sphere in $\mathrm{CuH}_{-1} \mathbf{L}^{\mathbf{1}}$.

The inhibition curves in the presence of copper(II)- $\mathbf{L}^{2}$ systems are depicted in Fig. 9, and the obtained kinetic parameters $\left(\mathrm{IC}_{50}\right.$ and $k$ ) are presented in Table 4, together with that of the native $\mathrm{Cu}, \mathrm{Zn}$-SOD and free copper(II) as comparison.

Both mono- and dinuclear copper(II)- $\mathbf{L}^{2}$ complexes were found to be able to dismutate the superoxide radical. At $0.1-1 \mu \mathrm{M} \mathrm{L} \mathbf{L}^{2}$ concentration and at $\mathrm{pH} 7.4, \mathrm{CuL}^{2} / \mathrm{CuH}_{-1} \mathbf{L}^{2}$ and $\mathrm{Cu}_{2} \mathrm{H}_{-1} \mathbf{L}^{2}$ complexes are the major species at 1:1 and 2:1 metal-to-ligand ratios, respectively (the concentration of the free copper(II) ion is negligible). The obtained $\mathrm{IC}_{50}$ values are similar for all copper(II) complexes of tripodal peptides (Table 4). These values indicate the highly efficient superoxide dismutating ability, although the best SOD mimicking copper(II)-peptide complexes, containing exclusively imidazole coordinated metal centers, exhibit a 2-3-fold higher activity $\left(\mathrm{IC}_{50}=0.084\right.$ and $\left.0.044 \mu \mathrm{M}\right) .^{25}$

Table $4 \quad I C_{50}$ and $k$ values determined in the $\mathrm{Cu}(\|)-\mathrm{L}^{2}$ systems, together with those of other copper(I)-tripodal peptide complexes and the native $\mathrm{Cu}, \mathrm{Zn}-\mathrm{SOD}$ enzyme

\begin{tabular}{llll}
\hline Complex & $\mathrm{IC}_{50}(\mu \mathrm{M})$ & $k^{a}\left(\mathrm{M}^{-1} \mathrm{~s}^{-1}\right)$ & Ref. \\
\hline $\mathrm{Cu}, \mathrm{Zn}-\mathrm{SOD}(\mathrm{pH} \mathrm{6.8)}$ & 0.0045 & $3.3 \times 10^{8}$ & 21 \\
$\mathrm{Cu}(\mathrm{II})-\mathbf{L}^{2} 2: 1(\mathrm{pH} \mathrm{7.4})$ & 0.13 & $4.6 \times 10^{7}$ & This work \\
$\mathrm{Cu}(\mathrm{II})-$ nta3his $^{b} 1: 1(\mathrm{pH} 7.4)$ & 0.13 & $2.3 \times 10^{7}$ & This work \\
$\mathrm{Cu}(\mathrm{II})-\operatorname{tren} 3 \mathrm{his}^{b} 1: 1(\mathrm{pH} 7.4)$ & 0.17 & $1.8 \times 10^{7}$ & This work \\
$\mathrm{Cu}(\mathrm{II})-\mathbf{L}^{2} 1: 1(\mathrm{pH} \mathrm{7.4})$ & 0.20 & $3.0 \times 10^{7}$ & This work \\
$\mathrm{Cu}\left(\mathrm{HPO}_{4}\right)(\mathrm{pH} 7.4)$ & 1.06 & $6.2 \times 10^{6}$ & 69
\end{tabular}

${ }^{a} k$ calculated as $k_{\mathrm{NBT}} \times[\mathrm{NBT}] / \mathrm{IC}_{50} \cdot{ }^{36}{ }^{b}$ Ligands and their copper(II) complexes were studied in our previous work. ${ }^{27}$

\section{Conclusions}

In this study, we extended our knowledge on the coordination chemistry of N-terminal histidine-containing tripodal peptides. Copper(II) complexes of the mono- and bis-functionalized tren derivatives, tren1his $\left(\mathbf{L}^{\mathbf{1}}\right)$ and tren2his $\left(\mathbf{L}^{\mathbf{2}}\right)$, respectively, are presented, focusing on solution equilibrium and catechol oxidase mimicking. The mono-His derivative $\mathbf{L}^{\mathbf{1}}$ forms only mononuclear complexes. Around $\mathrm{pH} 5$, the $\mathrm{CuHL}^{\mathbf{1}}$ complex predominates in the solution with the $\left\{\mathrm{N}_{\mathrm{im}}, \mathrm{N}^{-}, \mathrm{N}_{\text {tert }}, \mathrm{NH}_{2}{ }^{\text {tren }}\right\}$ type coordination. Above $\mathrm{pH} 8, \mathrm{CuH}_{-1} \mathbf{L}^{\mathbf{1}}$ is the only species in which the copper(II) ion has the $\left\{\mathrm{N}_{\mathrm{im}}, \mathrm{N}^{-}, \mathrm{N}_{\text {tert }}, \mathrm{NH}_{2}{ }^{\text {tren }}\right\}$ binding mode, i.e. the tren-like coordination is supplemented by an imidazole ring. In the case of $\mathbf{L}^{2}$, both mono- and dinuclear copper(II) species can be identified. In the acidic-neutral $\mathrm{pH}$ range, the highly stable bis-histamine-type binding mode dominates in the equimolar solution, while in basic $\mathrm{pH}$ amide coordinated complexes are present. The bis-histamine coordination in $\mathrm{CuHL}^{2}$ creates a preorganized structure which promotes the binding of a second metal at the tren-like binding site with $\left\{\mathrm{N}^{-}, \mathrm{N}_{\text {tert }}, \mathrm{N}^{-}\right\}$ coordination in $\mathrm{Cu}_{2} \mathrm{H}_{-1} \mathbf{L}^{2}$ and $\mathrm{Cu}_{2} \mathrm{H}_{-2} \mathbf{L}^{2}$.

Only the $\mathrm{Cu}_{2} \mathrm{H}_{-2} \mathbf{L}^{2}$ complex was found to efficiently catalyze the oxidation of $\mathrm{H}_{2}$ DTBC. The kinetic data resulted in a very high $k_{\text {cat }} / K_{\mathrm{M}}$ ratio (4360 $\mathrm{M}^{-1} \mathrm{~s}^{-1}$ ), which is due to the exceptionally strong substrate-binding ability of the dinuclear complex. Independent UV-vis and CD measurements confirmed the formation of a highly stable complex-substrate ternary adduct, bearing significantly different spectroscopic features as compared with the binary copper(II) complex. However, the oxidation of the substrate within this adduct, which is a common feature of catalytically active dicopper(II) complexes, does not occur in the absence of dioxygen. This finding implies that the role of dioxygen is the oxidation of the substrate activated by the dinuclear complex, and not the oxidation of the copper(I) species, as it was proposed for the native enzyme and for many dinuclear model compounds. We assume a $\mathrm{Cu}$ (II) $\mathrm{Cu}(\mathrm{II})$-catecholate- $\mathrm{Cu}$ (II) $\mathrm{Cu}$ (I)-semiquinone valence tautomer (VT) equilibrium. The semiquinone formed in small quantities reacts with dioxygen in a rate-determining step, which eventually results in products DTBQ and $\mathrm{H}_{2} \mathrm{O}_{2}$. The $\mathrm{Cu}$ (II)- $\mathbf{L}^{2}$ complexes also possess efficient superoxide dismutase-like activity, supporting the versatility of tripodal peptide complexes in redox enzyme mimicking.

\section{Conflicts of interest}

There are no conflicts to declare.

\section{Acknowledgements}

The research was supported by the National Research, Development and Innovation Office-NKFIH through projects GINOP-2.3.2-15-2016-00038, OTKA 101541 and TÉT_15-1-20160031. The authors are grateful to G. Krier and L. VernexLoset for MALDI-TOF MS measurements, A. Merlin for EPR measurements and S. Parant for technical help at Université de Lorraine. 


\section{References}

1 Z. Dai and J. W. Canary, New J. Chem., 2007, 31, 1708-1718.

2 M. Suzuki, Acc. Chem. Res., 2007, 40, 609-617.

3 N. Burzlaff, Adv. Inorg. Chem., 2008, 60, 101-165.

4 G. Parkin, New J. Chem., 2007, 31, 1996-2014.

5 A. Szorcsik, F. Matyuska, A. Bényei, N. V. Nagy, R. K. Szilágyi and T. Gajda, Dalton Trans., 2016, 45, 14998-15012.

6 M. M. Ibrahim and G. A. M. Mersal, J. Inorg. Biochem., 2010, 104, 1195-1204.

7 L. Szyrwiel, D. Lukacs, D. F. Sranko, Z. Kerner, A. Kotynia, J. Brasun, B. Setner, Z. Szewczuk, K. Malec and J. S. Pap, RSC Adv., 2017, 7, 24657-24666.

8 W. A. Chomitz and J. Arnold, Chem. - Eur. J., 2009, 15, 2020-2030.

$9 \mathrm{X} . \mathrm{Hu}$ and K. Meyer, J. Organomet. Chem., 2005, 690, 5474-5484.

10 G. Rapenne, Inorg. Chim. Acta, 2009, 362, 4276-4283.

11 F. Matyuska, A. Szorcsik, N. V. May, Á. Dancs, É. Kováts, A. Bényei and T. Gajda, Dalton Trans., 2017, 46, 8626-8642.

12 S. Tartaggia, O. De Lucchi, A. Gambaro, R. Zangrando, F. Fabris and A. Scarso, Chem. - Eur. J., 2013, 19, 5701-5714.

13 K. J. C. van Bommel, C. van der Pol, I. Muizebelt, A. Friggeri, A. Heeres, A. Meetsma, B. L. Feringa and J. van Esch, Angew. Chem., Int. Ed., 2004, 43, 1663-1667.

14 A. Timme, R. Kress, R. Q. Albuquerque and H.-W. Schmidt, Chem. - Eur. J., 2012, 18, 8329-8339.

15 S. Blanc, P. Yakirevitch, E. Leize, M. Meyer, J. Libman, A. Van Dorsselaer, A.-M. Albrecht-Gary and A. Shanzer, J. Am. Chem. Soc., 1997, 119, 4934-4944.

16 A.-S. Jullien, C. Gateau, I. Kieffer, D. Testemale and P. Delangle, Inorg. Chem., 2013, 52, 9954-9961.

17 H. B. Albada, F. Soulimani, B. M. Weckhuysen and R. M. J. Liskamp, Chem. Commun., 2007, 4895-4897, DOI: 10.1039/ B709400K.

18 M. Gelinsky, R. Vogler and H. Vahrenkamp, Inorg. Chem., 2002, 41, 2560-2564.

19 D. Árus, N. V. Nagy, Á. Dancs, A. Jancsó, R. Berkecz and T. Gajda, J. Inorg. Biochem., 2013, 126, 61-69.

20 E. Kopera, A. Krężel, A. M. Protas, A. Belczyk, A. Bonna, A. Wysłouch-Cieszyńska, J. Poznański and W. Bal, Inorg. Chem., 2010, 49, 6636-6645.

21 A. Jancsó, Z. Paksi, N. Jakab, B. Gyurcsik, A. Rockenbauer and T. Gajda, Dalton Trans., 2005, 3187-3194, DOI: 10.1039/ B507655B.

22 D. Árus, A. Jancsó, D. Szunyogh, F. Matyuska, N. V. Nagy, E. Hoffmann, T. Körtvélyesi and T. Gajda, J. Inorg. Biochem., 2012, 106, 10-18.

23 N. I. Jakab, A. Jancsó, T. Gajda, B. Gyurcsik and A. Rockenbauer, J. Inorg. Biochem., 2008, 102, 1438-1448.

24 Z. Paksi, A. Jancsó, F. Pacello, N. Nagy, A. Battistoni and T. Gajda, J. Inorg. Biochem., 2008, 102, 1700-1710.

25 S. Timári, R. Cerea and K. Várnagy, J. Inorg. Biochem., 2011, 105, 1009-1017.

26 Y. Jin and J. A. Cowan, J. Am. Chem. Soc., 2005, 127, 8408-8415.
27 Á. Dancs, N. V. May, K. Selmeczi, Z. Darula, A. Szorcsik, F. Matyuska, T. Páli and T. Gajda, New J. Chem., 2017, 41, 808-823.

28 Á. Dancs, K. Selmeczi, I. Bányai, Z. Darula and T. Gajda, Inorg. Chim. Acta, 2017, DOI: 10.1016/j.ica.2017.06.049.

29 F. J. C. Rosotti and H. Rosotti, The determination of stability constants, McGraw-Hill Book Co., New York, 1962.

30 E. Högfeldt, Stability Constants of Metal-Ion Complexes, Part A. Inorganic Ligands, Pergamon, New York, 1982.

31 L. Zékány, I. Nagypál and G. Peintler, PSEQUAD for chemical equilibria, Technical Software Distributors, Baltimore, MD, 1991.

32 A. Rockenbauer and L. Korecz, Appl. Magn. Reson., 1996, 10, 29-43.

33 R. G. Bates, M. Paabo and R. A. Robinson, J. Phys. Chem., 1963, 67, 1833-1838.

34 L. G. Hepler, E. M. Woolley and D. G. Hurkot, J. Phys. Chem., 1970, 74, 3908-3913.

35 D. R. Lide, CRC Handbook of Chemistry and Physics, Taylor and Francis, 88th edn, 2007-2008.

36 S. Durot, C. Policar, F. Cisnetti, F. Lambert, J.-P. Renault, G. Pelosi, G. Blain, H. Korri-Youssoufi and J.-P. Mahy, Eur. J. Inorg. Chem., 2005, 3513-3523.

37 A. Myari, G. Malandrinos, Y. Deligiannakis, J. C. Plakatouras, N. Hadjiliadis, Z. Nagy and I. Sóvágó, J. Inorg. Biochem., 2001, 85, 253-261.

38 N. I. Jakab, B. Gyurcsik, T. Körtvélyesi, I. Vosekalna, J. Jensen and E. Larsen, J. Inorg. Biochem., 2007, 101, 1376-1385.

39 A. P. Garnett and J. H. Viles, J. Biol. Chem., 2003, 278, 6795-6802.

40 E. Aronoff-Spencer, C. S. Burns, N. I. Avdievich, G. J. Gerfen, J. Peisach, W. E. Antholine, H. L. Ball, F. E. Cohen, S. B. Prusiner and G. L. Millhauser, Biochemistry, 2000, 39, 13760-13771.

41 G. Facchin, M. H. Torre, E. Kremer, E. J. Baran, A. Mombrú, H. Pardo, M. P. Araujo, A. A. Batista and A. J. Costa-Filho, Inorg. Chim. Acta, 2003, 355, 408-413.

42 I. Török, T. Gajda, B. Gyurcsik, G. K. Tóth and A. Péter, J. Chem. Soc., Dalton Trans., 1998, 1205-1212, DOI: 10.1039/ A707408E.

43 F. Matyuska, N. V. May, A. Benyei and T. Gajda, New J. Chem., 2017, 41, 11647-11660.

44 P. Lubal, M. r. Kývala, P. Hermann, J. Holubová, J. Rohovec, J. Havel and I. Lukeš, Polyhedron, 2001, 20, 47-55.

45 G. Greiner, L. Seyfarth, W. Poppitz, R. Witter, U. Sternberg and S. Reissmann, Lett. Pept. Sci., 2000, 7, 133-141.

46 K. Ösz, K. Várnagy, H. Süli-Vargha, D. Sanna, G. Micera and I. Sóvágó, Dalton Trans., 2003, 2009-2016, DOI: 10.1039/ B211413E.

47 T. Klabunde, C. Eicken, J. C. Sacchettini and B. Krebs, Nat. Struct. Mol. Biol., 1998, 5, 1084-1090.

48 N. Hakulinen, C. Gasparetti, H. Kaljunen, K. Kruus and J. Rouvinen, J. Biol. Inorg. Chem., 2013, 18, 917-929.

49 I. A. Koval, P. Gamez, C. Belle, K. Selmeczi and J. Reedijk, Chem. Soc. Rev., 2006, 35, 814-840.

50 K. S. Banu, T. Chattopadhyay, A. Banerjee, S. Bhattacharya, E. Suresh, M. Nethaji, E. Zangrando and D. Das, Inorg. Chem., 2008, 47, 7083-7093. 
51 I. A. Koval, K. Selmeczi, C. Belle, C. Philouze, E. Saint-Aman, I. Gautier-Luneau, A. M. Schuitema, M. van Vliet, P. Gamez, O. Roubeau, M. Lüken, B. Krebs, M. Lutz, A. L. Spek, J.-L. Pierre and J. Reedijk, Chem. - Eur. J., 2006, 12, 6138-6150.

52 E. Monzani, L. Quinti, A. Perotti, L. Casella, M. Gullotti, L. Randaccio, S. Geremia, G. Nardin, P. Faleschini and G. Tabbi, Inorg. Chem., 1998, 37, 553-562.

53 E. C. M. Ording-Wenker, M. A. Siegler, M. Lutz and E. Bouwman, Dalton Trans., 2015, 44, 12196-12209.

54 W. M. Tay, A. I. Hanafy, A. Angerhofer and L.-J. Ming, Bioorg. Med. Chem. Lett., 2009, 19, 6709-6712.

55 S. Dell'Acqua, V. Pirota, C. Anzani, M. M. Rocco, S. Nicolis, D. Valensin, E. Monzani and L. Casella, Metallomics, 2015, 7, 1091-1102.

56 S. K. Dey and A. Mukherjee, Coord. Chem. Rev., 2016, 310, 80-115.

57 K. Masahito, K. Tomohisa, K. Koji, T. Yoshimitsu, I. Shinobu and K. Shosuke, Bull. Chem. Soc. Jpn., 2003, 76, 1957-1964.

58 J. Ackermann, S. Buchler and F. Meyer, C. R. Chim., 2007, 10, 421-432.

59 A. Granata, E. Monzani and L. Casella, J. Biol. Inorg. Chem., 2004, 9, 903-913.

60 M. J. Sever and J. J. Wilker, Dalton Trans., 2004, 1061-1072, DOI: 10.1039/B315811J.
61 D. G. Brown, W. J. Hughes and G. Knerr, Inorg. Chim. Acta, 1980, 46, 123-126.

62 S. Torelli, C. Belle, S. Hamman, J.-L. Pierre and E. SaintAman, Inorg. Chem., 2002, 41, 3983-3989.

63 C. A. Tyson and A. E. Martell, J. Am. Chem. Soc., 1968, 90, 3379-3386.

64 J. Kaizer, J. Pap, G. Speier, L. Párkányi, L. Korecz and A. Rockenbauer, J. Inorg. Biochem., 2002, 91, 190-198.

65 G. Speier, Z. Tyeklár, P. Tóth, E. Speier, S. Tisza, A. Rockenbauer, A. M. Whalen, N. Alkire and C. G. Pierpont, Inorg. Chem., 2001, 40, 5653-5659.

66 J. Kaizer, T. Csay, G. Speier and M. Giorgi, J. Mol. Catal. A: Chem., 2010, 329, 71-76.

67 M. J. Gajewska, W.-M. Ching, Y.-S. Wen and C.-H. Hung, Dalton Trans., 2014, 43, 14726-14736.

68 G. Facchin, N. Veiga, M. G. Kramer, A. A. Batista, K. Várnagy, E. Farkas, V. Moreno and M. H. Torre, J. Inorg. Biochem., 2016, 162, 52-61.

69 L. L. Costanzo, G. de Guidi, S. Giuffrida, E. Rizzarelli and G. Vecchio, J. Inorg. Biochem., 1993, 50, 273-281.

70 B. Bóka, A. Myari, I. Sóvágó and N. Hadjiliadis, J. Inorg. Biochem., 2004, 98, 113-122.

71 J. M. McCord and I. Fridovich, J. Biol. Chem., 1969, 244, 6049-6055. 